\title{
Amino Acid Nutrition and Metabolism in Chickens
}

\author{
Wenliang He, Peng Li, and Guoyao Wu
}

\section{Abstract}

Both poultry meat and eggs provide highquality animal protein [containing sufficient amounts and proper ratios of amino acids (AAs)] for human consumption and, therefore, play an important role in the growth, development, and health of all individuals. Because there are growing concerns about the suboptimal efficiencies of poultry production and its impact on environmental sustainability, much attention has been paid to the formulation of low-protein diets and precision nutrition through the addition of low-cost crystalline AAs or alternative sources of animal-protein feedstuffs. This necessitates a better understanding of AA nutrition and metabolism in chickens. Although historic nutrition research has focused on nutritionally essential amino acids (EAAs) that are not synthesized or are inadequately synthesized in the body, increasing evidence shows that the traditionally classified nutritionally nonessential amino acids (NEAAs), such as glutamine and glutamate, have physiological and regulatory roles other than protein synthesis in chicken growth and egg production. In addition, like other avian

W. He $\cdot$ G. Wu $(\bowtie)$

Department of Animal Science, Texas A\&M University, College Station, TX, USA

e-mail: g-wu@tamu.edu

P. Li

North American Renderers Association, Alexandria, VA, USA species, chickens do not synthesize adequately glycine or proline (the most abundant AAs in the body but present in plant-source feedstuffs at low content) relative to their nutritional and physiological needs. Therefore, these two AAs must be sufficient in poultry diets. Animal proteins (including ruminant meat \& bone meal and hydrolyzed feather meal) are abundant sources of both glycine and proline in chicken nutrition. Clearly, chickens (including broilers and laying hens) have dietary requirements for all proteinogenic AAs to achieve their maximum productivity and maintain optimum health particularly under adverse conditions such as heat stress and disease. This is a paradigm shift in poultry nutrition from the 70-year-old "ideal protein" concept that concerned only about EAAs to the focus of functional AAs that include both EAAs and NEAAs.

\section{Keywords}

Amino acids - Protein - Nutrition - Growth · Health $\cdot$ Egg production

\section{Abbreviations}

$\begin{array}{ll}\text { AA } & \text { amino acid } \\ \text { BCAA } & \text { branched-chain amino acid } \\ \text { BW } & \text { body weight }\end{array}$


EAA nutritionally essential amino acid

ICV intracerebroventricular

NEAA nutritionally nonessential amino acid

NMDA N-methyl-D-aspartate

NRC National Research Council

POX proline oxidase

$\alpha$-KG $\quad \alpha$-ketoglutarate

\subsection{Introduction}

Amino acids (AAs) are the building blocks of protein, which is the major dry matter component of growth in chickens and their eggs (Baker 2009). As foods for humans, poultry and eggs provide high-quality protein that contains sufficient amounts and proper ratios of AAs, therefore playing an important role in the growth, development, and health of humans (McNeill et al. 2017; Réhault-Godbert et al. 2019). Chicken or poultry byproducts are also low-cost and high-quality protein feedstuffs for livestock species, fish, and companion animals ( $\mathrm{Li}$ and $\mathrm{Wu} 2020$ ). In addition, taurine (a nonproteinogenic AA), which is present abundantly in poultry tissues, is essential for the integrity and function of the eyes, heart and skeletal muscle, as well as the nervous, digestive, immune, and reproductive systems in both mammals and birds (Wu 2020a). As for other animals, adequate intakes of dietary AAs are crucial for the optimum efficiency of poultry production (Baker 2009). Either an excess or a deficiency of AAs has negative impacts on the health and productivity of chickens.

Compared with the chicken breeds used 30 years ago, modern breeds of broilers grow faster and gain more lean tissues, and modern breeds of leghorns lay more eggs (Applegate and Angel 2014; Bailey 2020). However, there is not much progress in our understanding of AA nutrition and metabolism in chickens over the past three decades (Bailey 2020). It is known that the patterns of free AAs in plasma and skeletal muscles of chickens (Table 7.1) differ from those in mammals (Wu 2018a, b) and that ammonia is removed primarily as uric acid in birds rather than as urea in mammals (Wu 2013).
Thus, there are distinct differences in AA metabolism and nutrition between avian and mammalian species. Because improving the efficiency of poultry production and sustaining the global environment are important goals of animal agriculture (Wu et al. 2020), much attention has been paid to the formulation of low-protein diets through the addition of low-cost crystalline AAs. This necessitates renewed interest in the fundamental knowledge of cell- and tissue-specific synthesis and catabolism of AAs in chickens. Although historic nutrition research has focused on nutritionally essential amino acids (EAAs) that are not synthesized or are inadequately synthesized in the body (Baker and Han 1994), increasing evidence shows that the traditionally classified nutritionally nonessential amino acids (NEAAs; coined in 1912) such as glutamine and glutamate have physiological and regulatory roles other than protein synthesis in chicken growth and egg production (Wu 2014, 2018a, b). The major objective of this article is to highlight recent advances in AA nutrition and metabolism in meat-type and egg-laying chickens.

\subsection{Digestion of Dietary Protein and Absorption of Its Hydrolysis Products in Chickens}

The digestive system of chickens differs from that of pigs, but these two species share common features of digestion and absorption (Wu 2018a). In birds, ingested feed passes through the esophagus into the crop (a temporary storage pouch) and then enters the proventriculus (also known as the "true stomach"). Within the proventriculus, feed is mixed with $\mathrm{HCl}$ and digestive enzymes as in mammals to initiate the hydrolysis of proteins and fats. This acid is produced from $\mathrm{NaCl}$ and carbonic acid $\left(\mathrm{H}_{2} \mathrm{CO}_{3}\right)$ by parietal cells in the gastric glands of the stomach to create an acidic environment (e.g., $\mathrm{pH}=2.5-3.5$; equivalent to $10^{-2.5}$ to $10^{-3.5} \mathrm{M}$ $\mathrm{HCl}$ ). Gastrin (released by the parietal cells of the stomach) and acetylcholine (released by the vagus nerve and enteric system) stimulate gastric 
Table 7.1 Concentrations of free amino acids in the plasma and skeletal muscles of 6-week-old fed and 48-h fasted male White Leghorn chickens ${ }^{\mathrm{a}}$

\begin{tabular}{|c|c|c|c|c|c|c|}
\hline \multirow{3}{*}{$\begin{array}{l}\text { Amino } \\
\text { acid }\end{array}$} & \multicolumn{3}{|l|}{ Fed chickens } & \multicolumn{3}{|c|}{ 48-h fasted chickens } \\
\hline & \multirow{2}{*}{$\begin{array}{l}\text { Plasma } \\
(\mathrm{nmol} / \mathrm{ml})\end{array}$} & $\begin{array}{l}\text { Gastrocnemius } \\
\text { muscle }\end{array}$ & $\begin{array}{l}\text { Pectoralis } \\
\text { muscle }\end{array}$ & \multirow{2}{*}{$\begin{array}{l}\text { Plasma } \\
(\mathrm{nmol} / \mathrm{ml})\end{array}$} & $\begin{array}{l}\text { Gastrocnemius } \\
\text { muscle }\end{array}$ & $\begin{array}{l}\text { Pectoralis } \\
\text { muscle }\end{array}$ \\
\hline & & \multicolumn{2}{|l|}{ (nmol/mg tissue) } & & \multicolumn{2}{|l|}{ (nmol/mg tissue) } \\
\hline Ala & $521 \pm 14$ & $3.21 \pm 0.15$ & $1.20 \pm 0.08$ & $616 \pm 8^{*}$ & $3.93 \pm 0.10^{*}$ & $1.70 \pm 0.09 *$ \\
\hline$\beta$-Ala & $44 \pm 7$ & $1.08 \pm 0.30$ & $0.83 \pm 0.13$ & $79 \pm 6^{*}$ & $1.49 \pm 0.15$ & $0.78 \pm 0.05$ \\
\hline Arg & $461 \pm 32$ & $0.40 \pm 0.03$ & $0.24 \pm 0.02$ & $297 \pm 13^{*}$ & $0.36 \pm 0.01$ & $0.26 \pm 0.02$ \\
\hline Asp & $65 \pm 5$ & $1.55 \pm 0.09$ & $0.31 \pm 0.02$ & $152 \pm 13^{*}$ & $0.74 \pm 0.05^{*}$ & $0.32 \pm 0.01$ \\
\hline Asn & $114 \pm 13$ & $0.41 \pm 0.04$ & $0.18 \pm 0.02$ & $86 \pm 11$ & $0.32 \pm 0.03$ & $0.21 \pm 0.04$ \\
\hline Cit & $1.01 \pm 0.03$ & $0.016 \pm 0.002$ & $0.015 \pm 0.001$ & $0.74 \pm 0.02 *$ & $0.014 \pm 0.001$ & $0.013 \pm 0.001$ \\
\hline Cys & $251 \pm 17$ & $0.23 \pm 0.02$ & $0.21 \pm 0.01$ & $173 \pm 12 *$ & $0.18 \pm 0.01 *$ & $0.17 \pm 0.01 *$ \\
\hline Gln & $1089 \pm 60$ & $9.45 \pm 0.64$ & $1.41 \pm 0.04$ & $941 \pm 26$ & $3.02 \pm 0.17 *$ & $1.38 \pm 0.07$ \\
\hline Glu & $265 \pm 22$ & $3.43 \pm 0.28$ & $0.90 \pm 0.06$ & $317 \pm 11 *$ & $1.69 \pm 0.12 *$ & $0.89 \pm 0.05$ \\
\hline Gly & $496 \pm 16$ & $1.05 \pm 0.14$ & $0.71 \pm 0.09$ & $709 \pm 28 *$ & $1.37 \pm 0.12$ & $0.80 \pm 0.08$ \\
\hline His & $138 \pm 7$ & $0.10 \pm 0.01$ & $0.14 \pm 0.02$ & $181 \pm 12^{*}$ & $0.32 \pm 0.03 *$ & $0.24 \pm 0.01 *$ \\
\hline Hyp & $103 \pm 6$ & $0.048 \pm 0.002$ & $0.043 \pm 0.002$ & $71 \pm 4^{*}$ & $0.044 \pm 0.002$ & $0.041 \pm 0.002$ \\
\hline Ile & $228 \pm 10$ & $0.21 \pm 0.02$ & $0.23 \pm 0.02$ & $241 \pm 9$ & $0.18 \pm 0.02$ & $0.19 \pm 0.02$ \\
\hline Leu & $305 \pm 24$ & $0.28 \pm 0.03$ & $0.32 \pm 0.05$ & $287 \pm 5$ & $0.31 \pm 0.04$ & $0.26 \pm 0.03$ \\
\hline Lys & $209 \pm 13$ & $0.47 \pm 0.06$ & $0.23 \pm 0.03$ & $446 \pm 26^{*}$ & $0.52 \pm 0.08$ & $0.26 \pm 0.04$ \\
\hline Met & $75 \pm 6$ & $0.094 \pm 0.006$ & $0.10 \pm 0.01$ & $77 \pm 2$ & $0.11 \pm 0.01$ & $0.12 \pm 0.02$ \\
\hline Orn & $20 \pm 2$ & $0.046 \pm 0.003$ & $0.032 \pm 0.002$ & $21 \pm 2$ & $0.042 \pm 0.003$ & $0.030 \pm 0.002$ \\
\hline Phe & $212 \pm 12$ & $0.19 \pm 0.03$ & $0.18 \pm 0.02$ & $244 \pm 5$ & $0.17 \pm 0.02$ & $0.20 \pm 0.02$ \\
\hline Pro & $349 \pm 21$ & $0.29 \pm 0.04$ & $0.24 \pm 0.02$ & $251 \pm 14^{*}$ & $0.27 \pm 0.02$ & $0.22 \pm 0.01$ \\
\hline Ser & $481 \pm 33$ & $1.60 \pm 0.15$ & $0.71 \pm 0.04$ & $503 \pm 31$ & $1.17 \pm 0.08 *$ & $0.84 \pm 0.06^{*}$ \\
\hline $\mathrm{Tau}$ & $249 \pm 33$ & $11.8 \pm 0.30$ & $0.45 \pm 0.06$ & $512 \pm 29^{*}$ & $9.20 \pm 0.42 *$ & $0.42 \pm 0.05$ \\
\hline Thr & $260 \pm 17$ & $0.77 \pm 0.09$ & $0.57 \pm 0.05$ & $294 \pm 10$ & $0.76 \pm 0.07$ & $0.66 \pm 0.05$ \\
\hline Trp & $68 \pm 2$ & $0.04 \pm 0.01$ & $0.05 \pm 0.01$ & $82 \pm 3^{*}$ & $0.06 \pm 0.01^{*}$ & $0.06 \pm 0.01$ \\
\hline Tyr & $171 \pm 10$ & $0.14 \pm 0.01$ & $0.16 \pm 0.01$ & $250 \pm 11^{*}$ & $0.21 \pm 0.02 *$ & $0.23 \pm 0.02 *$ \\
\hline Val & $288 \pm 19$ & $0.46 \pm 0.04$ & $0.33 \pm 0.03$ & $316 \pm 4$ & $0.40 \pm 0.04$ & $0.32 \pm 0.03$ \\
\hline
\end{tabular}

$\mathrm{Cit}=$ citrulline; $\mathrm{Hyp}=4$-hydroxyproline; Orn = ornithine; Tau $=$ taurine

${ }^{*} \mathrm{P}<0.05$ vs the Fed group as analyzed by unpaired t-test

${ }^{\mathrm{a}}$ Taken from Watford and $\mathrm{Wu}$ (2005). Data are means \pm SEM, $\mathrm{n}=5$

acid production. In contrast, somatostatin (also known as growth hormone-inhibiting hormone; produced by $\mathrm{D}$ cells in the stomach, the small and large intestine, and also the pancreas) and secretin (produced by the $\mathrm{S}$ cells of the duodenum) inhibit gastric acid secretion. Gastric $\mathrm{HCl}$ aids in protein digestion by: (1) converting inactive gastric proteases (pepsinogens A, B, C, and D and pro-chymosin, collectively called zymogens, which are synthesized and released by the chief cells of the gastric glands) to active proteases (pepsins A, B, C, and D, and chymosin); and (2) denaturing dietary proteins so that they lose their natural folded structures to expose their peptide bonds to the active proteases for hydrolysis.
The specific activities of pepsinogens A, B and C in the proventriculus increase progressively during the embryonic development, reach a temporary peak several days before hatching, and increase 30-fold within $24 \mathrm{~h}$ after hatching, in comparison with the values at birth, regardless of enteral feeding (Yasugi and Mizuno 1981). Dietary protein, AAs, histamine, acetylcholine, gastrin, gastrin-releasing peptide, vagal stimulation, and vasoactive intestinal peptide enhance the secretion of gastric proteases (Wu 2018a).

The digesta from the proventriculus enters the gizzard (ventriculus; also known as the mechanical stomach; $\mathrm{pH}=2.5-3.5$ ) for grinding, mixing and mashing. The digesta includes the large 
polypeptides, small peptides and free AAs resulting from the enzymatic hydrolysis by pepsins in the stomach, as well as dietary proteins that are resistant to pepsins in the stomach. The transit time of food particles through the proventriculus and gizzard is about $90 \mathrm{~min}$. Food particles from the gizzard, the food particles enter the small intestine for further digestion. The pancreas plays an essential role in the digestion of dietary protein because its acinar cells secrete pro-proteases into the lumen of the duodenum $(\mathrm{pH}=6.0-6.5)$. These enzymes are the zymogens of endopeptidases (trypsin, chymotrypsins A, B and C, collagenase, and elastase) and exopeptidases (carboxypeptidases A and B), and are activated in the duodenal lumen by a cascade of limited proteolysis by enterokinase to remove an $\mathrm{N}$-terminal oligopeptide (2 to 6 AA residues) from each zymogen. Specifically, enterokinase (released by enterocytes of the duodenum) converts trypsinogen into trypsin through the removal of an N-terminal hexapeptide. Subsequently, trypsin converts other pancreatic zymogens into active forms (e.g., chymotrypsins A, B and $\mathrm{C}$, elastase, and carboxypeptidases $\mathrm{A}$ and $\mathrm{B}$ ). In addition, aminopeptidases (exopeptidases; released by the mucosa of the small intestine) cleave the last peptide bond adjacent to an $\mathrm{AA}$ at the $\mathrm{NH}_{2}$ terminus. Furthermore, prolyl oligopeptidase (prolyl endopeptidase; released by the small intestine) cleaves proline or hydroxyproline from the inside of an oligopeptide that contains the imino acid.

The extracellular proteolysis occurring in the duodenum of poultry is limited due to the short length of this intestinal segment and a short transit time of food particles (about $7 \mathrm{~min}$ ). The chyme moves into the jejunum $(\mathrm{pH}=6.5-7.0)$, where most proteolysis takes place due to its long length and high protease activities. The transit time of the digesta through the jejunum is about $25 \mathrm{~min}$. Continuous digestion of protein and polypeptides can occur in the ileum $(\mathrm{pH}=7.0-7.4)$ if their hydrolysis is not completed in the jejunum, with the transit time of the digesta through the ileum being about $60 \mathrm{~min}$. The small peptides containing 4-6 AA residues are further hydrolyzed by peptidases that are bound primarily to the brush-border of enterocytes, and to a lesser extent, in the intestinal lumen to form free AAs, dipeptides, and tripeptides. Dipeptides (not containing imino acids, i.e., proline or hydroxyproline) and tripeptides are hydrolyzed by mucosa-derived dipeptidases and tripeptidases, respectively (Wu et al. 2011a). However, dipeptides containing an imino acid are cleaved by mucosa-derived prolidases. The true ileal digestibilities of AAs in the proteins of corn grain, soybean meal, sorghum grain, and meat \& bone meal are $85-89 \%, 86-91 \%$, $84-88 \%$, and $89-91 \%$, respectively, in chickens (Wu 2014).

Absorption of tripeptides and dipeptides by the enterocytes of small intestine occurs through the apical-membrane $\mathrm{Na}^{+}$-independent, $\mathrm{H}^{+}$-driven peptide transporter 1 (Gilbert et al. 2010). Sodium is indirectly required for this process because the needed protons are provided by the $\mathrm{Na}^{+} / \mathrm{H}^{+}$ exchange. Within the enterocytes, tri- and di-peptides are rapidly hydrolyzed by cytosolic peptidases to form free AAs. Because of the high activity of intracellular peptidases, a nutritionally significant quantity of peptides does not transcellularly enter the portal vein or the intestinal lymphatics (Wu 2018a). It is possible that a limited amount of special small peptides [e.g., those containing an imino acid (such as Gly-Pro-OH-Pro, a degradation product of collagen) or a formyl AA (e.g., N-formyl-Met-LeuPhe, a bacterial peptide serving as a chemotactic)] are absorbed intact from the luminal content to the bloodstream through M cells, exosomes, and enterocytes via transepithelial cell transport (Hou et al. 2017).

Free AAs in the intestinal lumen are absorbed by enterocytes primarily via (a) $\mathrm{Na}^{+}$-independent system (facilitated system; e.g., for basic AAs as well as small and large neutral AAs) and (b) $\mathrm{Na}^{+}-$ dependent system (active transport; e.g., for acidic AAs as well as small and large neutral AAs) (Matthews 2000). There are reports that elevating dietary AA intake increases the abundance of the $b^{0,+}$ AT mRNA in the jejunum of chickens (Osmanyan et al. 2018) and that dietary supplementation with L-methionine or DL-methionine promotes the expression of the 
$\mathrm{B}^{0} \mathrm{AT}$ transporter in the small intestine of broilers (Zhang et al. 2017a). The international Nomenclature Committee has named AA transporters according to their solute carrier families based on their gene sequence similarities. $\mathrm{Na}^{+}$-dependent AA transporters and $\mathrm{Na}^{+}$-independent AA transporters account for the uptake of $60 \%$ and $40 \%$ of free AAs from the lumen of the small intestine into enterocytes, respectively (Wu 2018a, b). Before binding to an AA, the $\mathrm{Na}^{+}$-dependent AA transporter binds to $\mathrm{Na}^{+}$ first, which will increase its affinity for the AA. As a result, both $\mathrm{Na}^{+}$and the AA are transported into the cytoplasm of the enterocyte. To maintain the balance of electrolytes within the enterocyte, the $\mathrm{Na}^{+} / \mathrm{K}^{+}$-ATPase in its basolateral membrane is responsible for pumping $\mathrm{Na}^{+}$out of the cell and getting $\mathrm{K}^{+}$into the cell at the expenditure of ATP.

In chickens, the apical membrane of enterocytes actively takes up AAs (including glutamine, glutamate and aspartate) from the lumen of the small intestine. At present, it is unknown about the percentages of dietary AAs entering the portal circulation of any poultry species. This issue can be addressed by cannulating the portal vein of chickens and obtaining blood samples from the portal vein at various time points after feeding for AA analyses, as performed in pigs (Wu et al. 1994). Alternatively, Ussing chambers can be used to assess the transfer of AAs (e.g., 0.5-5 mM glutamine, glutamate, or aspartate) from the luminal (apical, mucosal) side of the small intestine (e.g., jejunum) of chickens to the serosal (or basolateral, facing the blood) side of the gut, as performed in the pig small intestine (Wang et al. 2014). In pigs, about $70 \%$ of dietary glutamine (Wu et al. 2011a) and $97 \%$ of dietary glutamate (Hou and $\mathrm{Wu} 2018$ ) are utilized (primarily via oxidation to $\mathrm{CO}_{2}$ ) by the small intestine during the first pass into the portal vein. If this is also true for birds, most of the circulating glutamine and glutamate in their bodies must be derived from endogenous synthesis.

Based on the intakes of digestible AAs and the accretion of AAs in the body of 14- and 42-day-old broiler chickens, we estimate that the overall efficiency of digestible AAs for their growth is $65.5 \%$ and $60.3 \%$, respectively, with the rates for individual AAs differing greatly from $40 \%$ to $79 \%$, depending on age and diet (Tables 7.2 and 7.3). If substantial amounts of dietary AAs are catabolized by the small intestine (either enterocytes, luminal microbes, or both) as reported for pigs (Wu 2013), these efficiency values may be greater, particularly for older birds with more active microbes in the small intestine. If nearly all of the dietary glutamate is utilized by the small intestine in chickens as reported for mammals ( $\mathrm{Wu}$ 1998), glutamate must be synthesized endogenously from other AAs. We consider this to be highly possible. Nonetheless, in 14- and 42-day-old chickens fed rations containing $21.5 \%$ and $18.4 \%$ crude protein, respectively, all dietary AAs but glycine appear to meet requirements for growth at the rates of 36.3 and $112 \mathrm{~g}$ of body weight per day, respectively. This raises an important question of whether insufficient glycine intake may limit maximum growth of chickens and whether dietary supplementation with glycine can reduce the intake of total AAs by the birds without affecting their growth performance.

\subsection{Amino Acid Syntheses in Chickens}

Chickens, like other poultry species, do not form the carbon skeletons of the following thirteen proteinogenic AAs: arginine, cysteine, histidine, isoleucine, leucine, lysine, methionine, phenylalanine, proline, threonine, tryptophan, tyrosine, and valine ( $\mathrm{Wu}$ 2013). This is because the birds lack one or more of the enzymes (e.g., pyrroline5-carboxylate synthase, carbamoylphosphate synthase-I, and ornithine carbamoyltransferase) required for the biosynthesis of those carbon skeletons from non-AA materials. Except for arginine, cysteine, lysine, and threonine, the $\alpha$-ketoacids of the proteinogenic AAs can undergo transamination with glutamate to generate their corresponding L-AAs. However, chickens can convert: (1) phenylalanine into tyrosine in the liver and kidneys via the tetrahydrobiopterin-dependent phenylalanine hydroxylase, and (2) methionine into cysteine in the liver via the transsulfuration pathway 
Table 7.2 Utilization of proteinogenic amino acids in diet for the growth of 14-day-old broiler chickens ${ }^{\mathrm{a}}$

\begin{tabular}{|c|c|c|c|c|c|c|c|c|c|}
\hline \multirow[b]{2}{*}{ AAs } & \multicolumn{2}{|c|}{ AAs in diet } & \multirow[b]{2}{*}{$\begin{array}{l}\text { Intake of } \\
\text { digestible } \\
\text { AAs in diet } \\
(\text { g/day })^{b}\end{array}$} & \multicolumn{2}{|c|}{$\begin{array}{l}\text { AAs in the } \\
\text { body }\end{array}$} & \multirow[b]{2}{*}{$\begin{array}{l}\text { AA } \\
\text { accretion } \\
\text { in the body } \\
\text { (g/day) }\end{array}$} & \multirow[b]{2}{*}{$\begin{array}{l}\text { Digestible } \\
\text { AAs } \\
\text { catabolized to } \\
\mathrm{CO}_{2} \text { (g/day) }\end{array}$} & \multicolumn{2}{|c|}{$\begin{array}{l}\text { Percentage }(\%) \text { of } \\
\text { digestible AA }\end{array}$} \\
\hline & $\begin{array}{l}\% \text { of } \\
\text { diet } \\
\text { (as-fed } \\
\text { basis) }\end{array}$ & $\begin{array}{l}\mathrm{g} / \\
100 \mathrm{~g} \\
\text { AA }\end{array}$ & & $\begin{array}{l}\mathrm{g} / \\
100 \mathrm{~g} \\
\text { wet } \\
\text { weight }\end{array}$ & $\begin{array}{l}\mathrm{g} / \\
100 \mathrm{~g} \\
\text { AAs }\end{array}$ & & & $\begin{array}{l}\text { Oxidized } \\
\text { to } \mathrm{CO}_{2}\end{array}$ & $\begin{array}{l}\text { Deposited } \\
\text { in the } \\
\text { body }^{d}\end{array}$ \\
\hline Ala & 1.31 & 6.16 & 0.491 & 0.951 & 6.61 & 0.345 & 0.145 & 29.6 & 70.4 \\
\hline Arg & 1.44 & 6.77 & 0.546 & 0.975 & 6.78 & 0.354 & 0.192 & 35.2 & 64.8 \\
\hline Asn & 0.93 & 4.37 & 0.345 & 0.521 & 3.62 & 0.189 & 0.156 & 45.2 & 54.8 \\
\hline Asp & 1.31 & 6.16 & 0.491 & 0.618 & 4.30 & 0.224 & 0.266 & 54.3 & 45.7 \\
\hline $\mathrm{Cys}^{\mathrm{c}}$ & 0.51 & 2.40 & 0.186 & 0.219 & 1.52 & 0.079 & 0.106 & 57.2 & 42.8 \\
\hline Gln & 1.81 & 8.51 & 0.684 & 0.747 & 5.19 & 0.271 & 0.413 & 60.4 & 39.6 \\
\hline Glu & 1.70 & 7.99 & 0.647 & 1.190 & 8.28 & 0.432 & 0.216 & 33.3 & 66.7 \\
\hline Gly & 0.88 & 4.14 & 0.326 & 1.670 & 11.6 & 0.606 & -0.280 & -86.0 & 186.3 \\
\hline His & 0.55 & 2.58 & 0.202 & 0.306 & 2.13 & 0.112 & \begin{tabular}{|l|}
0.091 \\
\end{tabular} & 44.9 & 55.1 \\
\hline Ile & 0.88 & 4.14 & 0.333 & 0.513 & 3.57 & 0.186 & 0.146 & 44.0 & 56.0 \\
\hline Leu & 1.79 & 8.41 & 0.673 & 0.988 & 6.87 & 0.359 & 0.315 & 46.7 & 53.3 \\
\hline Lys & 1.40 & 6.58 & 0.514 & 0.881 & 6.13 & 0.320 & 0.194 & 37.8 & 62.2 \\
\hline Met & 0.52 & 2.44 & 0.196 & 0.273 & 1.90 & 0.099 & 0.097 & 49.3 & 50.7 \\
\hline Phe & 1.01 & 4.75 & 0.385 & 0.496 & 3.45 & 0.180 & 0.204 & 53.2 & 46.8 \\
\hline Pro & 1.52 & 7.14 & 0.564 & 1.224 & 8.51 & 0.445 & 0.120 & 21.2 & 78.8 \\
\hline Ser & 0.81 & 3.81 & 0.307 & 0.641 & 4.46 & 0.233 & 0.074 & 24.2 & 75.8 \\
\hline Thr & 0.87 & 4.09 & 0.317 & 0.521 & 3.62 & 0.189 & 0.128 & 40.4 & 59.6 \\
\hline Trp & 0.24 & 1.13 & 0.088 & 0.167 & 1.16 & 0.061 & 0.027 & 31.2 & 68.8 \\
\hline Tyr & 0.78 & 3.67 & 0.295 & 0.379 & 2.64 & 0.138 & 0.157 & 53.3 & 46.7 \\
\hline Val & 1.02 & 4.79 & 0.385 & 0.598 & 4.16 & 0.217 & 0.168 & 43.7 & 56.3 \\
\hline Hyp & ND & ND & & 0.499 & 3.47 & 0.181 & -0.181 & - & - \\
\hline
\end{tabular}

$A A$ amino acid, Hyp 4-hydroxyproline, $N D$ not detectable

${ }^{\mathrm{a}}$ Male broiler chickens (Cobb) were fed a corn- and soybean meal-based diet containing $21.5 \%$ crude protein. Values are means for 10 chickens. Amino acids in the diet and the animal body were analyzed by high-performance liquid chromatography after acid and alkaline hydrolyses as previously described ( $\mathrm{Li}$ and $\mathrm{Wu} \mathrm{2020)}$ and their values were calculated on the basis of the molecular weights of intact AAs. A negative value indicates net formation

${ }^{b}$ Feed intake was $170 \mathrm{~g} / \mathrm{kg}$ body weight per day. The mean body weight of 14-day-old broiler chickens was $297 \mathrm{~g}$, and their mean weight gain was $36.3 \mathrm{~g} / \mathrm{day}$. The true ileal digestibility (\%) of AAs in the diet was: Ala, 88.1; Arg, 89.3; Asn, 87.2; Asp, 88.1; Cys, 85.6; Gln, 89.0; Glu, 89.6; Gly, 87.6; His, 86.3; Ile, 88.9; Leu, 88.5; Lys, 86.4; Met, 88.6; Phe, 89.6; Pro, 87.3; Ser, 89.1; Thr, 85.7; Trp, 86.5; Tyr, 88.9; and Val, 88.8 (Wu 2014)

${ }^{\mathrm{c}}$ Total cysteine (cysteine plus $1 / 2$ cystine)

${ }^{\mathrm{d}}$ As protein and non-protein products

(Wu 2013). Tyrosine and cysteine can replace up to $50 \%$ of phenylalanine and methionine in the diets of chickens, respectively, depending on age and dietary nutrient composition (Baker 2009). In addition, relatively small amounts of ornithine and proline are produced from arginine via arginase, ornithine aminotransferase, and pyrroline-5carboxylate reductase (Austic 1973; Graber and Baker 1973; Wu et al. 1995). Arginase hydrolyzes arginine into ornithine and urea. The latter is excreted in urine. Thus, despite the lack of urea cycle in avian species, the body of poultry contains urea of non-dietary origin. Furthermore, a limited amount of citrulline is generated from arginine via nitric oxide synthase. This explains why the concentrations of ornithine and citrulline in the plasma of chickens is very low and negligible, respectively (Table 7.1), in comparison with pigs (Wu 2018a).

Chickens synthesize de novo an additional group of seven proteinogenic AAs (alanine, asparagine, aspartate, glutamate, glutamine, glycine, and serine), and some nonproteinogenic AAs (e.g., taurine and $\gamma$-aminobutyrate) in a 
Table 7.3 Utilization of proteinogenic amino acids in diet for the growth of 42-day-old broiler chickens ${ }^{\mathrm{a}}$

\begin{tabular}{|c|c|c|c|c|c|c|c|c|c|}
\hline \multirow[b]{2}{*}{ AAs } & \multicolumn{2}{|c|}{ AAs in diet } & \multirow[b]{2}{*}{$\begin{array}{l}\text { Intake of } \\
\text { digestible } \\
\text { AAs in diet } \\
(\text { g/day })^{b}\end{array}$} & \multicolumn{2}{|c|}{$\begin{array}{l}\text { AAs in the } \\
\text { body }\end{array}$} & \multirow[b]{2}{*}{$\begin{array}{l}\text { AA } \\
\text { accretion } \\
\text { in the body } \\
\text { (g/day) }\end{array}$} & \multirow[b]{2}{*}{$\begin{array}{l}\text { Digestible } \\
\text { AAs } \\
\text { catabolized to } \\
\mathrm{CO}_{2} \text { (g/day) }\end{array}$} & \multicolumn{2}{|c|}{$\begin{array}{l}\text { Percentage }(\%) \text { of } \\
\text { digestible AA }\end{array}$} \\
\hline & $\begin{array}{l}\% \text { of } \\
\text { diet } \\
\text { (as-fed } \\
\text { basis) }\end{array}$ & $\begin{array}{l}\mathrm{g} / \\
100 \mathrm{~g} \\
\text { AA }\end{array}$ & & $\begin{array}{l}\mathrm{g} / \\
100 \mathrm{~g} \\
\text { wet } \\
\text { weight } \\
\end{array}$ & $\begin{array}{l}\mathrm{g} / \\
100 \mathrm{~g} \\
\text { AAs }\end{array}$ & & & $\begin{array}{l}\text { Oxidized } \\
\text { to } \mathrm{CO}_{2}\end{array}$ & $\begin{array}{l}\text { Deposited } \\
\text { in the } \\
\text { body }^{d}\end{array}$ \\
\hline Ala & 0.93 & 5.08 & 1.36 & 0.944 & 6.55 & 1.057 & 0.302 & 22.2 & 77.8 \\
\hline Arg & 1.21 & 6.61 & 1.79 & 0.971 & 6.74 & 1.088 & 0.703 & 39.3 & 60.7 \\
\hline Asn & 0.76 & 4.15 & 1.10 & 0.519 & 3.60 & 0.581 & 0.518 & 47.1 & 52.9 \\
\hline Asp & 1.09 & 5.95 & 1.59 & 0.617 & 4.28 & 0.691 & 0.901 & 56.6 & 43.4 \\
\hline $\mathrm{Cys}^{\mathrm{c}}$ & 0.43 & 2.35 & 0.61 & 0.226 & 1.57 & 0.253 & 0.357 & 58.5 & 41.5 \\
\hline Gln & 1.62 & 8.85 & 2.39 & 0.741 & 5.14 & 0.830 & 1.561 & 66.3 & 33.7 \\
\hline Glu & 1.50 & 8.19 & 2.23 & 1.183 & 8.21 & 1.325 & 0.905 & 40.6 & 59.4 \\
\hline Gly & 0.76 & 4.15 & 1.10 & 1.712 & 11.9 & 1.917 & -0.819 & -74.6 & 174.6 \\
\hline His & 0.43 & 2.33 & 0.61 & 0.304 & 2.11 & 0.340 & 0.269 & 44.1 & 55.9 \\
\hline Ile & 0.75 & 4.10 & 1.11 & 0.511 & 3.55 & 0.572 & 0.535 & 48.3 & 51.7 \\
\hline Leu & 1.59 & 8.68 & 2.34 & 0.987 & 6.85 & 1.105 & 1.230 & 52.7 & 47.3 \\
\hline Lys & 1.16 & 6.33 & 1.66 & 0.880 & 6.11 & 0.986 & 0.673 & 40.6 & 59.4 \\
\hline Met & 0.47 & 2.57 & 0.69 & 0.272 & 1.89 & 0.305 & 0.385 & 55.8 & 44.2 \\
\hline Phe & 0.86 & 4.70 & 1.28 & 0.493 & 3.42 & 0.552 & 0.726 & 56.8 & 43.2 \\
\hline Pro & 1.41 & 7.70 & 2.04 & 1.236 & 8.58 & 1.384 & 0.657 & 32.2 & 67.8 \\
\hline Ser & 0.83 & 4.53 & 1.23 & 0.640 & 4.44 & 0.717 & 0.510 & 41.5 & 58.5 \\
\hline Thr & 0.75 & 4.10 & 1.07 & 0.518 & 3.59 & 0.580 & 0.486 & 45.6 & 54.4 \\
\hline Trp & 0.21 & 1.13 & 0.30 & 0.168 & 1.17 & 0.188 & 0.109 & 36.6 & 63.4 \\
\hline Tyr & 0.71 & 3.88 & 1.05 & 0.382 & 2.65 & 0.428 & 0.620 & 59.2 & 40.8 \\
\hline Val & 0.85 & 4.64 & 1.25 & 0.601 & 4.17 & 0.673 & 0.579 & 46.2 & 53.8 \\
\hline Hyp & ND & ND & ND & 0.507 & 3.52 & 0.568 & -0.568 & - & - \\
\hline
\end{tabular}

$A A$, amino acid; Hyp, 4-hydroxyproline; $N D$ not detectable

${ }^{a}$ Male broiler chickens (Cobb) were fed a corn- and soybean meal-based diet containing $18.4 \%$ crude protein. Values are means for 10 chickens. Amino acids in the diet and the animal body were analyzed by high-performance liquid chromatography after acid and alkaline hydrolyses as previously described (Li and $\mathrm{Wu} 2020)$ and their values were calculated on the basis of the molecular weights of intact AAs. A negative value indicates net formation

${ }^{b}$ Feed intake was $74 \mathrm{~g} / \mathrm{kg}$ body weight per day. The mean body weight of 42-day-old broiler chickens was $2245 \mathrm{~g}$, and their mean weight gain was $112.0 \mathrm{~g} /$ day. The true ileal digestibility (\%) of AAs in the diet was: Ala, 88.0; Arg, 89.1; Asn, 87.1; Asp, 88.1; Cys, 85.5; Gln, 89.0; Glu, 89.5; Gly, 87.0; His, 86.1; Ile, 88.9; Leu, 88.5; Lys, 86.2; Met, 88.4; Phe, 89.5; Pro, 87.2; Ser, 89.0; Thr, 85.6; Trp, 86.4; Tyr, 88.9; and Val, 88.7 (Wu 2014)

${ }^{\mathrm{c}}$ Total cysteine (cysteine plus $1 / 2$ cystine)

${ }^{\mathrm{d}}$ As protein and non-protein products

cell- and tissue-specific manner (Wu 2013). To date, compelling evidence shows that chickens fed conventional diets do not adequately synthesize glycine and proline relative to their metabolic needs (Baker 2009); therefore, these two AAs are classified as EAA for the birds (Wu 2009). Note that glutamate is the major excitatory neurotransmitter in the central nervous system ( $\mathrm{He}$ and $\mathrm{Wu}$ 2020). The transamination of branched-chain AAs (BCAAs; leucine, isoleucine and valine) with $\alpha$-ketoglutarate $(\alpha-\mathrm{KG}$; derived primarily from glucose metabolism) by BCAA transaminase generates glutamate, which is amidated with ammonia by the ATP-dependent glutamine synthetase to form glutamine. Glutamate is also transaminated with pyruvate or oxaloacetate by glutamate-pyruvate transaminase and glutamate-oxaloacetate transaminase to yield alanine and aspartate, respectively. Asparagine is synthesized from aspartate and glutamine by the ATP-dependent asparagine synthetase. Of note, $\alpha$-ketoisocaproate (the $\alpha$-ketoacid of leucine) may inhibit proteolysis in chicken skeletal muscle (Nakashima et al. 2007), which fulfils another 
Table 7.4 Use of dietary glycine for growth and uric acid production in broiler chickens fed corn- and soybean mealbased diets ${ }^{\mathrm{a}}$

\begin{tabular}{|c|c|c|c|c|c|c|c|}
\hline $\begin{array}{l}\text { Age of } \\
\text { chickens }\end{array}$ & $\begin{array}{l}\text { Feed intake } \\
(\mathrm{g} / \mathrm{kg} \mathrm{BW} \\
\text { per day) }\end{array}$ & $\begin{array}{l}\text { Digestible } \\
\text { glycine } \\
\text { intake }(\mathrm{g} / \mathrm{kg} \\
\text { BW per } \\
\text { day) }\end{array}$ & $\begin{array}{l}\text { Glycine } \\
\text { accretion in } \\
\text { the body } \\
\text { ( } / \mathrm{kg} \mathrm{BW} \\
\text { per day) }\end{array}$ & $\begin{array}{l}\text { Uric acid } \\
\text { excretion in } \\
\text { urine }(\mathrm{g} / \mathrm{kg} \\
\mathrm{BW} \text { per } \\
\text { day) }\end{array}$ & $\begin{array}{l}\text { Glycine } \\
\text { needed for } \\
\text { uric acid } \\
\text { production }{ }^{b} \\
\text { (g/kg BW } \\
\text { per day) }\end{array}$ & $\begin{array}{l}\text { Glycine } \\
\text { needed for } \\
\text { weight gain } \\
\text { and uric acid } \\
\text { production } \\
\text { (g/kg BW } \\
\text { per day) }\end{array}$ & $\begin{array}{l}\text { Dietary } \\
\text { glycine } \\
\text { meeting } \\
\text { glycine } \\
\text { needed for } \\
\text { weight gain } \\
\text { and uric acid } \\
\text { production } \\
(\%)\end{array}$ \\
\hline $\begin{array}{l}\text { Days } \\
7-14\end{array}$ & $180.5 \pm 2.9$ & $1.44 \pm 0.03$ & $2.05 \pm 0.05$ & $5.63 \pm 0.19$ & $2.51 \pm 0.08$ & $4.57 \pm 0.09$ & $30.8 \pm 0.19$ \\
\hline $\begin{array}{l}\text { Days } \\
35-42\end{array}$ & $75.6 \pm 0.55$ & $0.51 \pm 0.01$ & $0.98 \pm 0.01$ & $1.88 \pm 0.04$ & $0.84 \pm 0.02$ & $1.82 \pm 0.02$ & $28.2 \pm 0.11$ \\
\hline
\end{tabular}

$B W$ body weight

${ }^{a}$ Values are means \pm SEM, $n=4$ pens. Cobb male broiler chickens were fed $21.5 \%$ and $18.4 \%$ crude-protein diets (cornand soybean meal-based) between days 7 and 14 and between days 35 and 42 of age, respectively. There were 10 birds per pen. The mean body weight of the chickens was 36, 118, 297, 1489 and $2245 \mathrm{~g}$ at $0,7,14,35$, and 42 days of age, respectively. The content of glycine in the whole bodies of 14- and 42-day-old broilers were 1.65 and $1.68 \mathrm{~g} / 100 \mathrm{~g}$ of body weight, respectively

${ }^{\mathrm{b}}$ Calculated on the basis of the fact that one mole of glycine is required to synthesize 1 mole of uric acid (Wu 2013). Uric acid was determined as described by Flynn and Wu (1996)

physiological function of leucine. Due to its large mass, skeletal muscle [constituting $40-45 \%$ of body weight $(\mathrm{BW})]$ is the major site for the syntheses of glutamate, glutamine and alanine in chickens, with both glutamine and alanine participating in inter-organ metabolism of AAs (Wu et al. 1989). Thus, glutamine is the most abundant free $\alpha$-AA in the plasma and gastrocnemius muscle (a skeletal muscle) of chickens (Table 7.1). The avian liver is also an active organ for the syntheses of glutamate, aspartate, and alanine, but contributes to little or no net synthesis of glutamine due to its use for uric acid synthesis (the major route of ammonia detoxification in birds) under physiological conditions.

Plant-based diets are deficient in glycine and proline relative to protein synthesis in chickens (Hou et al. 2019; Li et al. 2011; Li and Wu 2020). We determined that the typical corn- and soybean meal-based diets for 7- to 14-day-old and 35- to 42-day-old broiler chickens provide $30.8 \%$ and $28.2 \%$ of the glycine needed for weight gain and uric acid production in the body, respectively (Table 7.4). Assuming that the amounts of glycine used for the syntheses of creatine, purines, glutathione, hippurate, and heme as well as the oxidation to $\mathrm{CO}_{2}$ and water (i.e., 0.91 and $0.36 \mathrm{~g}$ glycine/kg BW per day in 7- to 14- and 35- to 42-day-old male broiler chickens, respectively) represents $20 \%$ of the needs for weight gain plus uric acid production (Wang et al. 2013; Wu 2010), the needs for all glycine-dependent metabolic pathways are 5.48 and $2.18 \mathrm{~g}$ glycine $/ \mathrm{kg}$ BW per day in 7- to 14- and 35- to 42-day-old male broiler chickens, respectively. In other words, the diets provided $25.7 \%$ and $23.5 \%$ of the glycine required by 7 - to 14-day-old and 35to 42-day-old broiler chickens, respectively. Thus, the rapidly growing bird must synthesize daily at least $74-76 \%$ of the needed glycine, as reported for young pigs (Wang et al. 2014). This AA is synthesized endogenously from threonine, serine (via glucose and glutamate), and 4-hydroxyproline (a product of collagen degradation) via multiple pathways in a cell-and tissuespecific manner involving primarily the liver, kidney, and skeletal muscle ( $\mathrm{Li}$ and $\mathrm{Wu} 2018$ ). For example, glycine is formed from serine in the liver and kidneys via serine hydroxymethyltransferase (present in both the mitochondria and cytosol), from threonine in the liver, and from 4-hydroxyproline in almost all tissues (Wu et al. 2019). Because of a small amount of choline in the diet, this substance is a minor source of glycine in the body. Glycine is the most abundant AA in the body of chickens (Wu 2013). This is 
consistent with its diverse roles in the metabolism and physiology. For example, glycine is required for the syntheses of glutathione (the most abundant low-molecular-weight antioxidant in cells), heme (a component of hemoglobin, myoglobin, and heme-containing enzymes), and bilirubin (a vehicle for iron excretion via feces and urine). This AA also regulates the expression of proteases to inhibit protein degradation in chicken skeletal muscle (Nakashima et al. 2008). Glycine is also a major inhibitory neurotransmitter in the spinal cord and lower brainstem to regulate the behavior and function of the animals ( $\mathrm{He}$ and $\mathrm{Wu}$ 2020). In addition to glycine, chickens are not able to synthesize adequately proline to meet their nutritional and physiological requirements (Baker 2009).

\subsection{Amino Acid Catabolism in Chickens}

In mammals (e.g., rats, pigs, and humans), it is now known that not all digestible AAs enter the portal circulation and that all individual proteinogenic AAs present in the lumen of the small intestine undergo catabolism by enterocytes, intestinal microbes, or both at various rates (Wu 2013). At present, little is known about this key aspect of protein nutrition in any poultry species. In mammals, among all the AAs in the arterial blood, only glutamine is absorbed by the basolateral membrane of the enterocyte in the post-absorptive state (Wu 2013). This is because the basolateral membrane of the enterocyte expresses glutamine transporters but no or low levels of transporters for other AAs. In adult rats and young pigs, the small intestine takes up about $30 \%$ of glutamine but no glutamate or aspartate from the arterial blood in the post-absorptive state (Wu 1998). It is unknown whether this is also true for poultry. Both in vivo (e.g., jejunal cannulation) and in vitro (e.g., Ussing chambers) techniques can be used to address this important issue.

Poultry can degrade all the twenty proteinogenic AAs in a cell- and tissue-specific manner to form ammonia and their respective carbon skeletons such as pyruvate, oxaloacetate, and $\alpha-K G$ (Wu 2013). For example, there is little degradation of asparagine in the small intestine (Porteous 1980) but this AA is hydrolyzed by asparaginase in the liver and kidneys of chickens to aspartate and ammonia (Coon and Balling 1984). Except for BCAAs, the avian liver is the major site for initiating and completing the catabolism of these AAs to form ammonia. This organ has a limited ability to transaminate BCAAs due to low BCAA transaminase activity under physiological conditions. In contrast, skeletal muscle converts BCAAs and $\alpha-K G$ into their respective $\alpha$-ketoacids [i.e., branched-chain $\alpha$-ketoacids (BCAAs)] and glutamate in chickens ( $\mathrm{Wu}$ and Thompson 1987). As noted previously, glutamine and alanine (neutral AAs) are formed from glutamate as vehicles for the inter-organ transport of carbon and nitrogen atoms of AAs. In extrahepatic tissues, such as skeletal muscle, small intestine, and heart, some of the BCKAs undergo oxidative decarboxylation but most of them are released to the blood stream. The liver is the major organ to take up BCKAs in the blood for either oxidation to $\mathrm{CO}_{2}$, glucose synthesis (except for the $\alpha$-ketoacid of leucine), and ketogenesis. Tissues of birds can convert: (1) citrulline into arginine via argininosuccinate synthase and lyase, and (2) ornithine into $\alpha-K G$ via ornithine aminotransferase and pyrroline-5-carboxylate dehydrogenase. The latter is primarily expressed in the liver. There is negligible catabolism of taurine in animals (including poultry), and it is excreted from the body via either urine as a free AA or bile salt in feces.

In contrast to mammals, the liver of birds has a very low activity of phosphate-activated glutaminase (Coon and Balling 1984; Watford and $\mathrm{Wu} 2005$ ) such that hydrolysis of glutamine to glutamate and ammonia is limited in this organ. Like mammals (Wu et al. 1991), the skeletal muscles of chickens express glutaminase to degrade glutamine (Wu et al. 1998). Table 7.5 summarizes the activities of glutaminase in the liver, skeletal muscle and small intestine of chickens. The low activity of hepatic glutaminase ensures the synthesis of uric acid from ammonia via the formation of glutamine and subsequently purine nucleosides in the liver ( Wu 2013). Notes that adenosine and guanosine are generated from not only glutamine but also glycine, aspartate, formate, ribose-5-phosphate, bicarbonate and ATP. Compared with ureagenesis in mammals, 
Table 7.5 Activities of glutaminase, glutamine synthetase, and rates of protein synthesis in tissues of 6-week-old fed and 48-h fasted male White Leghorn chickens ${ }^{\mathrm{a}}$

\begin{tabular}{l|l|l|l|l}
\hline \multirow{2}{*}{ Tissue } & $\begin{array}{l}\text { Nutritional } \\
\text { state }\end{array}$ & $\begin{array}{l}\text { Activity of phosphate- activated } \\
\text { glutaminase (unit/g wet weight of } \\
\text { tissue) }\end{array}$ & $\begin{array}{l}\text { Activity of glutamine } \\
\text { synthetase (unit/g wet weight } \\
\text { of tissue) }\end{array}$ & $\begin{array}{l}\text { Fractional rate of } \\
\text { protein synthesis } \\
(\% / d a y)\end{array}$ \\
\hline \multirow{2}{*}{ Liver } & Fed & $0.67 \pm 0.02(6)$ & $1.68 \pm 0.09(4)$ & $128.4 \pm 7.5(5)^{\mathrm{b}}$ \\
\cline { 2 - 5 } & $48-\mathrm{h}$ fasted & $0.61 \pm 0.05(6)$ & $1.75 \pm 0.08(5)$ & $52.6 \pm 3.8^{*}(5)^{\mathrm{b}}$ \\
\hline \multirow{2}{*}{ GM } & Fed & $0.39 \pm 0.03(3)$ & $0.50 \pm 0.04(4)$ & $36.1 \pm 1.50(5)$ \\
\cline { 2 - 5 } & $48-\mathrm{h}$ fasted & $0.28 \pm 0.04(4)$ & $0.73 \pm 0.03^{*}(5)$ & $13.6 \pm 0.55^{*}(5)$ \\
\hline \multirow{2}{*}{ PM } & Fed & $1.67 \pm 0.09(4)$ & $0.07 \pm 0.01(4)$ & $10.5 \pm 0.86(5)$ \\
\cline { 2 - 5 } & 48 -h fasted & $1.28 \pm 0.16(4)$ & $0.08 \pm 0.01(5)$ & $10.3 \pm 0.81(5)$ \\
\hline \multirow{2}{*}{ Kejunum } & Fed & $0.14 \pm 0.02(5)$ & $0.034 \pm 0.002(5)$ & $96.3 \pm 4.6(5)^{\mathrm{b}}$ \\
\cline { 2 - 5 } & $48-\mathrm{h}$ fasted & $0.12 \pm 0.02(5)$ & $0.031 \pm 0.002(5)$ & $41.8 \pm 2.3^{*}(5)^{\mathrm{b}}$ \\
\hline & Fed & $8.22 \pm 0.53(6)$ & ND & $48.6 \pm 2.4(5)^{\mathrm{b}}$ \\
\hline
\end{tabular}

$G M$ gastrocnemius muscle, $N D$ not detected, $P M$ pectoralis muscle

${ }^{*} P<0.05$ vs. the fed group

adapted from Watford and $\mathrm{Wu}$ (2005) and $\mathrm{Wu}$ et al. (1998). Values are means \pm SEM. The number of animals is indicated in the parentheses. One unit represents $1 \mu \mathrm{mol}$ of product formed per minute at $38^{\circ} \mathrm{C}$

${ }^{\mathrm{b}}$ Rates of fractional protein synthesis were measured as described by Watford and $\mathrm{Wu}(2005)$

more energy is required for uric acid generation per removal of one ammonia molecule, resulting in the release of more heat. This explains, in part, why the basal metabolic rate and body temperatures are higher in birds than in mammals (e.g, pigs, rats and humans). Because ammonia is toxic to the central nervous system, it must be removed via uric acid production (the primary route for detoxification) and other biochemical pathways such as glutamine and glutamate syntheses in avian species.

Physiologically important products of AA catabolism in animal cells include polyamines (putrescine, spermidine and spermine). These substances are essential to the synthesis of DNA and proteins and, therefore, the rapid growth and development of all animals, including chickens (Agostinelli 2020). However, metabolic pathways for polyamine synthesis in avian tissues are largely unknown. In chickens, expression of arginase is relatively low and pyrroline-5-carboxylate synthase is absent in all tissues (Wu et al. 1995). At present, little is known about proline oxidase (POX) for polyamine synthesis in avian tissues. Recently, we found that arginase and POX activities are present only in the mitochondrial fraction of the kidneys of chickens between 0 and 21 days of age (Furukawa et al. 2018). Renal POX activity was greater on day 7 than Day 0 , but no change in renal arginase activity was detected during this period. Accordingly, there were age-dependent changes in the syntheses of ${ }^{14} \mathrm{C}$-putrescine, ${ }^{14} \mathrm{C}$-spermidine and ${ }^{14} \mathrm{C}$-spermine from $\left[\mathrm{U}_{-}{ }^{14} \mathrm{C}\right]$ arginine or $\left[\mathrm{U}_{-}{ }^{14} \mathrm{C}\right]$ proline in the chicken kidneys. Interestingly, concentrations of putrescine, spermidine and spermine in the plasma of chickens were about 10-, 100-, and ten-fold greater, respectively, than those in plasma from mammals. Consistent with enzymatic activities and polyamine syntheses, concentrations of polyamines in the kidney and plasma were greater on day 7 than day 0 , but then values decreased on days 21 and 42. Thus, results of this study reveal that polyamines are synthesized from arginine via arginase and proline via POX in the chicken kidneys and that polyamines released from the kidneys into blood provide polyamines for extrarenal tissues. This new knowledge helps to better understand the nutritional biochemistry of arginine and proline in birds.

\subsection{Inter-organ Metabolism of Glutamate and Glutamine in Chickens}

Because of the versatile and enormous roles of glutamine and glutamate in metabolism and physiology as noted previously, the past four decades 
have witnessed growing interest in the inter-organ metabolism of glutamate and glutamine in chickens. In the skeletal muscle of chickens, glutamate and glutamine can be synthesized and degraded, with the intracellular glutamineglutamate cycle regulating the release of glutamine from this organ (Wu et al. 1991). The rate of the oxidation of glutamate in the muscle is generally lower than the rate of the synthesis of glutamine from glutamate (Wu and Thompson 1987). In chickens, the rates of the oxidation of glutamate and glutamine are greater in the breast muscle (mainly glycolytic fibers) than in the leg muscle (mainly oxidative fibers) ( $\mathrm{Wu}$ et al. 1991, 1998). This explains why the concentration of glutamine is much lower in the breast muscle than in leg muscles (Table 7.1). In addition, extensive metabolism of both AAs occurs in the liver, small intestine, brain, and kidneys (Smith and Campbell 1983; Tinker et al. 1986; Watford et al. 1981; Watford and Wu 2005). The synthesis of glutamine from glutamate is of physiological significance for directly scavenging free ammonia in the blood and other tissues.

In the avian small intestine, glutamine and fructose-6-phosphate are known as substrates for the synthesis of glucosamine-6-phosphate and, thus, glycoproteins (including mucins and membrane receptors) ( $\mathrm{Wu} 2013$ ). In addition, glutamine is capable of activating the mechanistic target of rapamycin signaling pathway to stimulate tissue protein synthesis and animal growth. Because of limited glutaminase activity and abundant glutamine content in common feedstuffs for poultry diets, the concentration of glutamine in the plasma of chickens is about $1 \mathrm{mM}$, which doubles the concentration of glutamine in the plasma of mammals (Wu 2018a, b). In contrast, the concentration of glutamate in plasma is relatively low $(<100 \mu \mathrm{M})$ in poultry, although glutamate is abundant in common feedstuffs for poultry diets. This can be now explained by a high rate of glutamate oxidation and utilization by the enterocytes of chickens (He et al. 2018), as reported for rats and humans (Reeds et al. 2000) as well as pigs (Hou and $\mathrm{Wu} 2018$ ) and fish (Li et al. 2020a). It is likely that glutamate is utilized as a substrate for intestinal glutathione synthesis by poultry (Porteous 1980).
A previous study showed that the rate of glutamine consumption by chicken enterocytes was higher than that of proline, serine, glutamate, aspartate, asparagine, and glucose at $2.5 \mathrm{mM}$ for each amino acid and $5 \mathrm{mM}$ for glucose (Porteous 1980). The author also showed that the rate of glutamate consumption was only $20 \%$ of that for glucose. In contrast, Wu et al. (1995) reported that the enterocytes of growing chickens had a low activity of glutaminase and a limited ability to utilize this AA. Similarly, He et al. (2018) reported that chicken enterocytes had a low rate of catabolizing glutamine, but extensively degraded both glutamate and aspartate via reactions initiated primarily by transaminases to provide the majority of ATP. This basic research is highly significant because energy metabolism is the basis of life (Wu 2018a).

The liver of chickens takes up glutamine from the arterial blood at a higher rate in the fasting state than in the fed state (Tinker et al. 1986). In contrast, the liver of chickens in the fed state actively takes up glutamate, and the hepatic uptake of glutamate is the highest among all the amino acids measured, including glutamine, arginine, alanine and aspartate (Tinker et al. 1986). Due to the low glutaminase activity in the liver of chickens (Table 7.5), glutamine is mainly used to synthesize purine and pyrimidine nucleotides. The purine can be further converted into uric acid, which is an important antioxidant in birds (Fang et al. 2002). In contrast, the liver of chickens can readily degrade glutamate by either glutamate dehydrogenase or glutamate transaminases (e.g., glutamate-pyruvate transaminase and glutamate-oxaloacetate transaminase), with the carbon skeletons of glutamate being mainly converted into $\mathrm{CO}_{2}$ and water. This is because, in avian hepatocytes, phosphoenolpyruvate carboxykinase is localized exclusively in mitochondria and, therefore, glutamate is not converted into glucose in these cells under fed or fasting conditions (Watford et al. 1981). This aspect of hepatic amino acid metabolism in birds is distinct from that in mammals.

In contrast to pigs (Hou and $\mathrm{Wu} 2018$ ), the kidneys of chickens in the fed state take up glutamine from the arterial blood, but not glutamate (Tinker et al. 1986). In the long-term (6-day) 
fasting state, there is no uptake of both glutamine and glutamate by the chicken kidneys (Tinker et al. 1986). In avian renal tubules, phosphoenolpyruvate carboxykinase is present in both the cytosol and mitochondria, which allows for the production of glucose from glutamate under both fed and fasting conditions (Watford et al. 1981). This is significant for the regulation of glucose homeostasis in birds (Wu 2018a). When renal glutamate dehydrogenase activity is enhanced under acidotic conditions, the glutamate-derived ammonia contributes to the regulation of acidbase balance in the whole body (Curthoys and Watford 1995).

\subsection{Amino Acid Nutrition in Poultry}

\subsubsection{Growth Performance}

Chickens grow fast and respond sensitively to the dietary intakes of AAs (Baker 2009). This is consistent with a relatively high rate of protein synthesis in their skeletal muscles (Table 7.5). In addition, growth is also associated with the accretion of free AAs (particularly taurine, $\gamma$-aminobutyrate, glutamate and glutamine) in tissues, including skeletal muscle and brain (Tomonaga et al. 2004, 2005). Because of the differences in genetic selection, environment, and dietary composition, modern breeds of chickens have different requirements for AAs than the breeds used 30 years ago (Bailey 2020). Although previous studies reported that adult roosters did not need dietary glutamate or glutamine to maintain their body at a zero or positive nitrogen balance when fed a purified diet during the 3-day experimental period (Leveille and Fisher 1959), dietary glutamate and glutamine are vital for chickens to maintain a zero or positive nitrogen balance for long-term growth and survival (Maruyama et al. 1976). Note that nitrogen balance is not highly sensitive to assess dietary requirements for all AAs in animals within a short period time ( $\mathrm{Wu}$ 2014). One longer-term study (> a 14-day period) demonstrated that the absence of glutamate from diets decreased the BW gain of 1- to 14-day-old chickens fed a purified diet, while $10 \%$ of glutamate supplementation to a glutamate-free basal diet increased the BW gain of young chickens by four-fold (Maruyama et al. 1976).

Much evidence shows that, due to the limited activities of arginase (Klain and Johnson 1962) and proline oxidase (Furukawa et al. 2018) in chickens for glutamine synthesis from arginine and proline, dietary glutamine is of great significance for the health (including intestinal health) and growth of birds, particularly under stress conditions (Awad et al. 2014). In support of this notion, dietary supplementation with glutamine or feed-grade glutamine plus glutamate stimulates muscle protein synthesis and whole-body growth in broiler chickens ( $\mathrm{Li}$ et al. 2010). This finding is consistent with the report that glutamine stimulates protein synthesis and inhibits proteolysis in chick skeletal muscle in vitro (Wu and Thompson 1990). Co-supplementation with glutamate and glutamine mitigated on muscle catabolism in heat-stressed broiler chickens by inhibiting intramuscular proteolysis (Furukawa et al. 2020). Similarly, supplementing 0.2\%, $0.4 \%$, or $0.8 \%$ glutamine to a corn- and soybean meal-based diet for laying hens housed at 25-30 ${ }^{\circ} \mathrm{C}$ improved small-intestinal and oviduct morphologies; the circulating levels of luteinizing hormone, follicle stimulating hormone, triiodothyronine and tetraiodothyronine; and egg production (Dong et al. 2010). Furthermore, dietary supplementation with $0.5 \%$ or $1 \%$ glutamine to broilers raised under hot conditions $\left(30-34{ }^{\circ} \mathrm{C}\right)$ enhanced feed intake, serum insulin concentration, tissue integrity, and body-weight gain (Hu et al. 2016a), while improving the waterholding capacity, moisture and color of meat (Hu et al. 2016b). These findings establish that growing chickens cannot synthesize enough glutamine to meet their growth requirements.

Besides glutamate and glutamine, there is continued interest in the nutrition of EAAs in chickens. Dietary supplementation with lysine or methionine for 21- to 42-day-old broilers increased their growth rate through changes in metabolic pathways, as well as polygenic and pleiotropic relationships (Zhai et al. 2016). 
Likewise, dietary supplementation with lysine (Zarghi et al. 2020) or tryptophan (Mund et al. 2020) above the NRC (1994)-recommended levels had positive effects on growth performance, tissue development, immune responses, and antioxidant status in broiler chickens. However, excessive supplementation with tryptophan increased risks for pulmonary arterial pressure and induced plexiform lesion (Kluess et al. 2012). Therefore, caution must be exercised to formulate AA-balanced diets for chickens. Furthermore, elevating dietary AA density for broilers enhanced feed efficiency and breast muscle yield, while reducing fat pad yield (Johnson et al. 2020). Interestingly, although dietary methionine $(0.50 \%$ and $0.43 \%$ for starter and finisher diets, respectively) is sufficient to support the growth of broiler chickens with a normal hatching weight, this may not be the case for chickens with a low hatching weight. Thus, supplementing $0.1 \%$ DL-methionine to the diet for the chickens with a low hatching weight augmented their average daily BW gain, food intake, and the growth of breast muscle (Wen et al. 2014). Wen et al. (2014) explained that the beneficial effects of dietary supplementation of DL-methionine may be mediated by increases in IGF-I synthesis, as well as the expression of genes for the TOR/4EBP1 and FOXO4/atrogin-1 pathway.

Based on findings from studies with rats (Fu et al. 2005; Jobgen et al. 2009) and pig (Tan et al. 2009) that arginine reduces white fat accretion, much attention has been directed to such a novel role of this AA in poultry. For example, dietary supplementation with arginine $(0.25-1.00 \%)$ from 21 to 42 days of age of broilers reduced the abdominal fat deposition without any side effect on meat flavor or quality (Fouad et al. 2013). The underlying mechanisms include: (1) reductions in the expression of lipogenic genes in the liver and abdominal fat tissue (Pirsaraei et al. 2017); (2) improvements in blood metabolic profiles (including hematology; Oso et al. 2017) and the development of immune organs (e.g., thymus and spleen; Oso et al. 2017); (3) enhancement in immunity, as shown by amelioration of immunosuppression in chickens inoculated with infectious bursal disease virus (Tan et al. 2014); (4) alleviation of oxidative stress and inflammation (Yazdanabadi et al. 2020); and (5) decreases in Salmonella counts in the small intestine (Oso et al. 2017).

With the availability of low-cost feed-grade EAAs, two or more of their combinations have been used to improve the growth performance of chickens. For example, Emadi et al. (2011) reported that dietary supplementation of the combination of arginine plus tryptophan above the NRC (1994) requirements not only enhanced their growth performance but also had a positive immunomodulatory effect on innate (interferon$\alpha$ ), cellular (interferon- $\gamma$ ) and humoral (immunoglobulin G) immune responses in broiler chickens challenged with an infectious bursal disease vaccine. In addition, supplementation with glycine plus threonine increased the growth performance of 21- to 35-day-old broiler chickens fed diets based exclusively on plant-source feedstuffs with low protein levels (Ospina-Rojas et al. 2013). Furthermore, supplementing a mixture of AAs $(0.3 \%$ Leu, $0.2 \%$ Gly, $0.2 \%$ Pro, $0.2 \%$ Ala, $0.6 \%$ Asp, and $0.6 \%$ Glu) to a reduced-protein (18\% crude protein) diet for broilers (days 6-21) enhanced body-weight gain and feed efficiency without affecting feed intake, compared with the control group fed an $18 \%$ crude protein diet (Corzo et al. 2005).

\subsubsection{Neurological Function and Feed Intake}

AAs are known to modulate neurological function in animals (He and $\mathrm{Wu} 2020$ ). Intracerebroventricular (ICV) injection of L-proline inhibited spontaneous activity and increased sleeping posture of chicks in a dose-dependent manner (Hamasu et al. 2009). The sedative and hypnotic effects induced by L-Pro was mediated by N-methyl-D-aspartate (NMDA) receptors (Hamasu et al. 2010). In addition, L-Ser, L-Asp, D-Asp, L-Trp, D-Pro, L-Pro, L-Glu, glutathione, or creatine has been reported to inhibit spontaneous activity and attenuate adverse stress behaviors in chicks (Asechi et al. 2006; Erwan et al. 2012; Erwan et al. 2014; Yoshida et al. 
2012; Yamane et al. 2009a, b). However, the mechanisms responsible for the sedative effects of these AAs are different. Specifically, L-Ser inhibits the social separation stress-induced behaviors, which is mediated by $\gamma$-aminobutyrate A receptors. L-Asp induces sedative and hypnotic effects via NMDA receptors, whereas L-Pro, D-Pro, and glutamate exert the same effects via NMD, glycine, and NMDA plus AMPA receptors, respectively. In contrast, D-Asp reduces stress response through the simultaneous involvement of other receptors besides the NMDA receptor. These receptors are proteins, indicating an important role of AAs in overall neural network, behavior, and food intake (Tran et al. 2019). For example, there are reports that: (1) ICV injection of L-leucine increased the food intake of neonatal chicks, while the other two BCAAs or $\alpha$-ketoisocaproate had no effect (Izumi et al. 2004); (2) ICV injection of L-ornithine, carnosine, L-His, $\beta$-Ala, and histamine to neonatal chicks decrease their food intake (Tran et al. 2016; Tomonaga et al. 2004; Kawakami et al. 2000); these AAs are potential acute satiety signals in the brain of neonatal chicks; (3) the effect of L-Pro on food intake by neonatal chicks varied with feeding status, with ICV injection of L-Pro stimulating food intake under free access conditions but decreasing food intake in the fasting state (Haraguchi et al. 2007). To translate these discoveries into feeding, studies involving dietary supplementation of one or more AAs should be conducted with poultry.

\subsubsection{Anti-oxidative and Anti-inflammatory Reactions}

Glycine, arginine, glutamine, methionine, cysteine, tryptophan, proline, taurine, and creatine have anti-oxidative and anti-inflammatory functions in animals, including chicks (Sestili et al. 2011; Wu 2013). This line of research is still active in the field of poultry nutrition. For example, Xiao et al. (2018) reported that taurine enhanced antioxidant status in the duodenum and ameliorated lipopolysaccharide-induced intestinal inflammation in chickens by improving mitochondrial membrane permeability and goblet cell function. The anti-oxidative property of taurine also protects cardiomyocytes from oxidative injury, as taurine supplementation enhanced the levels of antioxidant molecules (e.g., glutathione, superoxide dismutase and glutathione peroxidase) and inhibited apoptosis in the cardiomyocytes of broilers with right ventricular hypertrophy (Li et al. 2020b). Furthermore, adding glycine-Zn chelates to the diet of broiler chickens enhanced the antioxidative capacity of their skeletal muscle and reduced the concentration of malondialdehyde (a product of lipid peroxidation), thereby improving meat quality (Winiarska-Mieczan et al. 2020).

\subsubsection{Revisit of the Ideal Protein Concept in Chicken Nutrition}

Animals have requirements for dietary AAs but not protein (Wu 2018a). Growth of poultry is characterized by the deposition of not only protein but also free AAs. The latter (e.g., free glutamate, glutamine, aspartate and asparagine) can constitute a significant proportion of the total AA pool in the body and, therefore, should not be neglected when considering dietary AA requirements (Wu 2013). Unfortunately, chemical analysis of these AAs in feedstuff and body proteins was not developed until the work of $\mathrm{Li}$ et al. (2011). The century-old term "NEAA" has recently been recognized as a misnomer in nutritional sciences and should be replaced by a new term, AASA (an AA that is synthesizable de novo in animal cells (Hou and Wu 2017).

The "ideal protein" concept has played a seminal role in advancing the development of AA nutrition in chickens over the past 70 years. However, this nutritional concept has flaws due to the limited knowledge of tissue-specific AA metabolism and underdeveloped analytical tools in the 1950s-1970s. The "ideal protein" concept has now been recognized to have significant shortcomings because it ignores nutritionally and physiologically important NEAAs in dietary formulations (Wu 2014). Revisiting the historic milestones in the development of the "ideal protein" concept will provide nutritional scientists with "foods" for thoughts. 
Beginning in the late 1950s, researchers at the University of Illinois conceptualized an ideal protein (optimal proportions and amounts of EAAs) for diets of chickens (Glista et al. 1951; Fisher and Scott 1954). This concept concerned only EAAs but no NEAAs. Early attempts to define an ideal protein were based on the composition of EAAs in casein and chicken eggs, but were largely unsuccessful partly because of the imbalances and excessive amounts of many EAAs. Several years later, Klain et al. (1960) simulated the profile of EAAs in the chick carcass to design a revised pattern of dietary EAAs in the ideal protein. An improvement in the growth performance of broilers was achieved with the revised ideal protein, but remained largely unsatisfactory.

Subsequently, a mixture of four AAs (cystine, glycine, proline, and glutamic acid), which are synthesized from methionine or other AAs by birds and had previously been thought to be NEAAs in chicken nutrition, was used in dietary formulations to yield better results on growth performance in broilers (Baker et al. 1968; Graber and Baker 1973). The extensive research during the 1960s and the 1970s culminated in several versions of the "chick AA requirement standard" for the first 3 weeks post-hatching (Dean and Scott 1965; Huston and Scott 1968; Sasse and Baker 1973). The reference values for EAAs were revised by Baker and Han (1994) to improve their balance in diets. The common features shared by these different recommended standards of dietary requirements of chickens for EAAs are that the diets included: (a) all proteinogenic EAAs that are not synthesized de novo by poultry; (b) several AAs (glutamic acid, glycine, and proline) that are synthesized de novo by birds to various extents; and (c) no data on alanine, aspartate, asparagine, glutamine, or serine.

It is noteworthy that the patterns of AA composition in the ideal protein for chicks, as proposed by the Scott and Baker groups, differed substantially for glycine and proline, and, to a lesser extent, for branched-chain AAs, histidine, and sulfur-containing AAs (Dean and Scott 1965; Huston and Scott 1968; Sasse and Baker 1973; Baker and Han 1994). These differences may reflect variations in the AA composition of chickens reported in the literature (Price et al. 1953; Robel and Menge 1973). Because the content of proline plus hydroxyproline, as well as glutamate, glutamine, aspartate and asparagine, in the body of chickens was not known at that time, the relatively small amount of proline in the recommended ideal protein was only arbitrarily set and the diets still contained no glutamine, aspartate or asparagine, which are all highly abundant in the body (Wu 2013). In contrast, a very large amount of glutamic acid (e.g., 13 times the lysine value in the modified Sasse and Baker Reference Standard) was used to presumably meet the entire need for "nonspecific AA nitrogen". However, key questions regarding whether glutamic acid fulfilled this role and whether excessive glutamic acid might interfere with the transport, metabolism and utilization of other AAs in chickens were not addressed by the University of Illinois researchers. Possibly due to these concerns and the publication of the NRC (1994) nutrient requirements for poultry, Baker (1997) excluded glutamic acid, glycine or proline from the ideal protein for the diets of 0 - to 56-day-old broiler chickens in his final version of the Ideal Ratios of Amino Acids for the birds. This is unfortunate but reflects an inadequate understanding of AA biochemistry and nutrition in poultry at the earlier times. Recent advances in nutrition research indicate that chickens, just like swine, have dietary requirements for NEAAs under certain physiological and environmental conditions (Wu 2014, 2018a). These NEAAs are now considered to be conditionally essential AAs in diets and play crucial roles in supporting the health and the maximum growth and egg-laying of chickens, as noted previously. Thus, sufficient NEAAs in diets are critical for improving the efficiency of poultry and egg production worldwide.

\subsubsection{Texas A\&M University's Optimal Ratios of AAs for Chickens}

The composition of AAs in diets differ from that in the skeletal muscle protein of broiler chickens (Tables 7.3 and 7.6) because dietary AAs are catabolized in animal tissues to different extents 


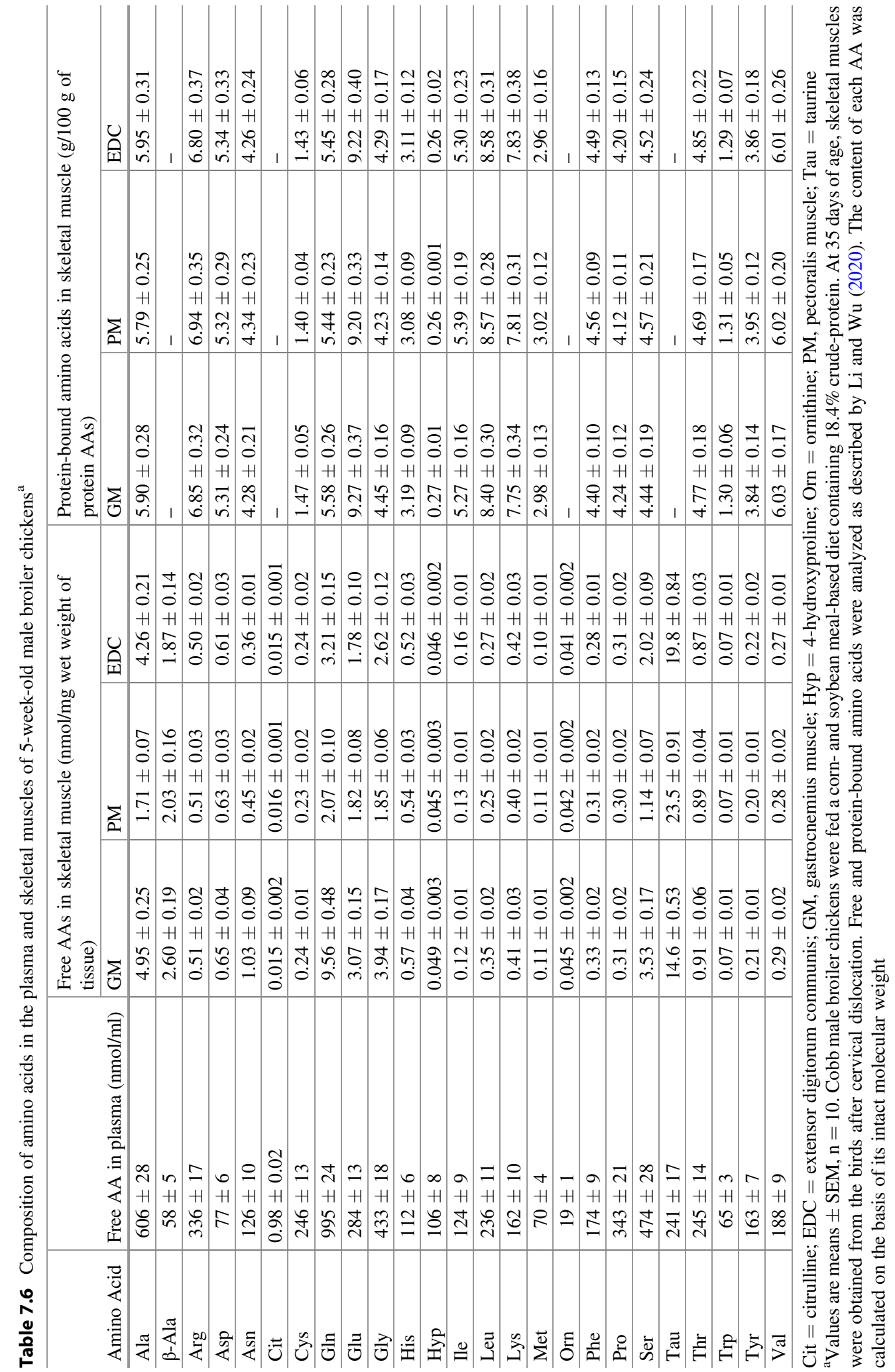


Table 7.7 Texas A\&M University's optimal ratios of true digestible amino acids in diets for growing broilers ${ }^{\mathrm{a}}$

\begin{tabular}{|c|c|c|c|c|c|}
\hline \multirow[b]{3}{*}{ AA } & \multicolumn{3}{|c|}{ Age of broiler chickens } & \multicolumn{2}{|l|}{ Laying hens ${ }^{\mathrm{b}}$} \\
\hline & $\begin{array}{l}0 \text { to } \\
21 \text { days }^{c}\end{array}$ & $\begin{array}{l}21 \text { to } \\
42 \text { days }^{d}\end{array}$ & $\begin{array}{l}42 \text { to } \\
56 \text { days }^{\mathrm{e}}\end{array}$ & \multirow{2}{*}{$\begin{array}{l}\text { Content of digestible AAs in diet } \\
(\% \text {, as-fed basis })\end{array}$} & \multirow{2}{*}{$\begin{array}{l}\text { Percentage of digestible } \\
\text { lysine in diet }(\%)\end{array}$} \\
\hline & \multicolumn{3}{|c|}{ (\% of digestible lysine in diet) } & & \\
\hline Alanine & 102 & 102 & 102 & 0.90 & 110 \\
\hline Arginine & 105 & 108 & 108 & 1.03 & 126 \\
\hline Asparagine & 56 & 56 & 56 & 0.72 & 88 \\
\hline Aspartate & 66 & 66 & 66 & 1.03 & 126 \\
\hline Cysteine & 32 & 33 & 33 & 0.29 & 35 \\
\hline Glutamate & 178 & 178 & 178 & 1.45 & 177 \\
\hline Glutamine & 128 & 128 & 128 & 1.58 & 193 \\
\hline Glycine & 176 & 176 & 176 & 1.00 & 120 \\
\hline Histidine & 35 & 35 & 35 & 0.41 & 50 \\
\hline Isoleucine & 67 & 69 & 69 & 0.70 & 85 \\
\hline Leucine & 109 & 109 & 109 & 1.52 & 185 \\
\hline Lysine & 100 & 100 & 100 & 0.82 & 100 \\
\hline Methionine & 40 & 42 & 42 & 0.38 & 46 \\
\hline Phenylalanine & 60 & 60 & 60 & 0.53 & 65 \\
\hline Proline & 184 & 184 & 184 & 1.31 & 160 \\
\hline Serine & 69 & 69 & 69 & 0.80 & 98 \\
\hline Threonine & 67 & 70 & 70 & 0.61 & 74 \\
\hline Tryptophan & 16 & 17 & 17 & 0.19 & 23 \\
\hline Tyrosine & 45 & 45 & 45 & 0.41 & 50 \\
\hline Valine & 77 & 80 & 80 & 0.78 & 95 \\
\hline
\end{tabular}

Adapted from Wu (2014)

${ }^{\mathrm{a}}$ Except for glycine, all amino acids are L-isomers. Values are based on true ileal digestible amino acids

${ }^{\mathrm{b}}$ A diet that consists of $60 \%$ corn grain (containing $9.3 \%$ crude protein) and $24 \%$ soybean meal (43.5\% crude protein) and is supplemented with $0.2 \%$ glycine and $0.1 \%$ L-methionine can meet the requirements of laying hens for all amino acids ${ }^{\mathrm{c}}$ Patterns of amino acid composition in the ideal protein are the same for male and female chickens. The amounts of digestible lysine in diet (as-fed basis; $90 \%$ dry matter) are $1.12 \%$ and $1.02 \%$ for male and female chickens, respectively ${ }^{\mathrm{d}}$ Patterns of amino acid composition in the ideal protein are the same for male and female chickens. The amounts of digestible lysine in diets (as-fed basis; $90 \%$ dry matter) are $0.89 \%$ and $0.84 \%$ for male and female chickens, respectively ${ }^{\mathrm{e}}$ Patterns of amino acid composition in the ideal protein are the same for male and female chickens. The amounts of digestible lysine in diets (as-fed basis; $90 \%$ dry matter) are $0.76 \%$ and $0.73 \%$ for male and female chickens, respectively

and some AAs are synthesized in a tissue-specific manner at various rates ( $\mathrm{Wu} 2013$ ). As noted previously, AAs (e.g., glutamate and glutamine) that are present in the free pool at high concentrations (Table 7.6), as well as glycine and proline (the most abundant AAs in the body), should be taken into consideration when defining dietary requirements of chickens for AAs. Based on the recent advances in the nutrition and metabolism of AAs, particularly the functional AAs (Wu 2010), Wu (2014) proposed the Texas A\&M University's optimal ratios of true digestible AAs in diets for growing broiler chickens during different growth phases (Table 7.7). This is consistent with the recent findings that animals (including poultry) have particularly high requirements for dietary glutamate, glutamine, glycine and proline. These AAs are very abundant in rendered animal sources of feedstuffs, such as blood meal, feather meal, ruminant meat \& bone meal, and poultry by-products ( $\mathrm{Li}$ et al. 2011). In addition, hydrolyzed feather meal is an abundant source of both glycine and proline in chicken nutrition. In contrast, plant-source feedstuffs contain relatively low content of both glycine and proline (Hou et al. 2019; Li and Wu 2020).

The Texas A\&M University's optimal ratios of dietary AAs for chickens (Wu 2014) are expected to beneficially reduce dietary protein content and 
nitrogen excretion, while improving the efficiency of nutrient utilization, growth and production performance, as well as sustaining the global animal agriculture. It is noteworthy that this new nutritional concept is now widely used to guide the practice of poultry feeding worldwide (e.g., Badawi et al. 2019; Belloir et al. 2017; Chrystal et al. 2020; Dessimoni et al. 2019; Liu et al. 2016; Refaie et al. 2017; Zhang et al. 2017b).

The productivity of modern laying hens has increased but their BW has decreased, when compared with breeds used decades ago (Bailey 2020). This means that the requirements (maintenance plus production) of the hens for dietary AAs must be revised to modify those recommended by NRC (1994). As for growing chickens, the ideal protein concept without the consideration of AAs that are synthesized in the body has also been applied to the formulation of diets for laying hens (Lemme 2009). At present, only Arg, Ile, Lys, Met + Cys, Thr, Trp, and Val are considered in various ideal AA profiles proposed by different authors (see Lemme 2009 for review). This is unfortunate, because AAs (e.g., glutamate, glutamine, glycine and proline) that are synthesized by the egg-laying birds may not meet their requirements for their maximum productivity or optimum health (including intestinal health). For example, there is evidence that the provision of glutamine from corn- and soybean meal-based diets (containing 18\% crude protein) is insufficient for the maintenance of a healthy gut or a healthy oviduct in laying hens and that dietary supplementation with $0.4 \%$ or $0.8 \%$ glutamine is needed to sustain their normal morphology (Dong et al. 2010). It is likely that: (1) as reported for broilers (He et al. 2018), the small intestine of laying hens uses dietary glutamate and aspartate as the major metabolic fuels; and (2) as indicated for broilers (Table 7.4), dietary glycine is inadequate for protein accretion and the detoxification of ammonia as uric acid in laying hens.

Although common feedstuffs contain both EAAs and NEAAs, dietary requirements of laying hens for all proteinogenic AAs (including glutamate, glutamine, glycine, serine, proline and tyrosine) must be recommended to guide both research and the feeding practices.
Methionine is usually the first limiting AA in the typical diets for laying hens, and there is evidence that supplementing $0.1 \%$ methionine to a corn- and soybean meal-based diet containing $16 \%$ crude protein and $0.29 \%$ methionine enhances egg production (Calderon and Jensen 1990). Furthermore, supplementation with $0.4 \%$ or $0.8 \%$ glutamine to a corn- and soybean mealbased diet for laying hens for 42 days augmented their egg production (Dong et al. 2010). Similar findings were reported by Gholipour et al. (2017) for laying guinea fowls fed a corn- and soybean meal-based diet containing $18 \%$ crude protein. Based on these considerations and research findings, we proposed Texas A\&M University's optimal ratios of AAs for laying eggs to further stimulate research in this field. Animal-source feedstuffs are good sources of all AAs for these animals ( $\mathrm{Li}$ and $\mathrm{Wu}$ 2020). Laying hens have a particularly high requirement for glutamine, leucine, glutamate, proline, arginine aspartate and glycine, because these AAs are highly abundant in the maternal bodies and in eggs. Inclusion of 4-hydroxyproline (a precursor of glycine; $\mathrm{Li}$ and $\mathrm{Wu}$ 2018) and taurine (a product of cysteine catabolism) in diets may reduce the requirements of laying hens for dietary glycine and cysteine, respectively. Both 4-hydroxyproline and taurine are highly abundant in animal-source feedstuffs (Li and $\mathrm{Wu} 2020$ ). These findings have important implications for improving the nutrition of zoo birds (Herring et al. 2020).

\subsection{Conclusion}

AAs are not only the building blocks of proteins but also signaling molecules, neurotransmitters, and regulators of metabolic pathways. Although AAs have been classified as EAAs or NEAAs for animals since 1912, growing evidence shows that a sufficient provision of NEAAs (e.g., glutamine, glutamate, glycine, and proline) is necessary for the optimal growth and health of chickens, including broilers and laying hens. Thus, the concept of "ideal protein", which was based solely on EAAs and ignored all AAs that are synthesized in the animals, is not ideal in animal nutrition. Ideal diets for poultry must provide all physiologically 
and nutritionally essential AAs (including EAAs and NEAAs) to maximize their growth performance and productivity, while promoting optimum health. To achieve this goal, we have proposed the Texas A\&M University's optimal ratios of dietary amino acids for growing broilers and laying hens. These data are expected to facilitate the formulation of low-protein diets and precision nutrition through the addition of low-cost crystalline AAs or their alternative sources of animal proteins. Feedstuffs of animal origin can provide AAs (including leucine, lysine, methionine, arginine, glutamate, glutamine, aspartate, glycine, and proline) to prepare AA-balanced diets for chickens and help sustain the global animal agriculture.

Acknowledgments This work was supported by Texas A\&M AgriLife Research (H-8200). We thank Dr. Christopher A. Bailey and Dr. Huaijun Zhou for assistance in our studies and helpful discussions.

\section{References}

Agostinelli E (2020) Biochemical and pathophysiological properties of polyamines. Amino Acids 52:111-117

Applegate TJ, Angel R (2014) Nutrient requirements of poultry publication: history and need for an update. $\mathrm{J}$ Appl Poult Res 23:567-575

Asechi M, Tomonaga S, Tachibana T, Han L, Hayamizu K, Denbow DM, Furuse M (2006) Intracerebroventricular injection of 1-serine analogs and derivatives induces sedative and hypnotic effects under an acute stressful condition in neonatal chicks. Behav Brain Res 170:71-77

Austic RE (1973) Conversion of arginine to proline in the chick. J Nutr 103:999-1007

Awad EA, Zulkifli I, Farjam AS, Chwen LT (2014) Amino acids fortification of low-protein diet for broilers under tropical climate. 2. Nonessential amino acids and increasing essential amino acids. Ital $\mathrm{J}$ Anim Sci 13:3297

Badawi MS, Ali AH, El-Razik WMA, Soliman MH (2019) Influence of low crude protein diets on broiler chickens performance. Adv Anim Vet Sci 7:26-33

Bailey CA (2020) Precision poultry nutrition and feed formulation. In: Bazer FW, Lamb GC, Wu G (eds) Animal agriculture: challenges, innovations, and sustainability. Elsevier, New York, pp 367-378

Baker DH (1997) Ideal amino acid profiles for swine and poultry and their applications in feed formulation. BioKyowa Tech Rev 9:1-24
Baker DH (2009) Advances in protein-amino acid nutrition of poultry. Amino Acids 37:29-41

Baker DH, Han Y (1994) Ideal amino acid profile for chicks during the first three weeks posthatching. Poult Sci 73:1441-1447

Baker DH, Sugahara M, Scott HM (1968) The glycineserine interrelationship in chick nutrition. Poult Sci 47:1376-1377

Belloir P, Méda B, Lambert W, Corrent E (2017) Reducing the CP content in broiler feeds: impact on animal performance, meat quality and nitrogen utilization. Animal 11:1881-1889

Calderon VM, Jensen LS (1990) The requirement for sulfur amino acid by laying hens as influenced by the protein concentration. Poult Sci 69:934-944

Chrystal PV, Moss AF, Khoddami A, Naranjo VD, Selle PH, Liu SY (2020) Effects of reduced crude protein levels, dietary electrolyte balance, and energy density on the performance of broiler chickens offered maizebased diets with evaluations of starch, protein, and amino acid metabolism. Poult Sci 99:1421-1431

Coon C, Balling R (1984) Asparagine and glutamine metabolism in chicks. Poult Sci 63:717-729

Corzo A, Fritts CA, Kidd MT, Kerr BJ (2005) Response of broiler chicks to essential and non-essential amino acid supplementation of low crude protein diets. Anim Feed Sci Technol 118:319-327

Curthoys NP, Watford M (1995) Regulation of glutaminase activity and glutamine metabolism. Annu Rev Nutr 15:133-159

Dean WF, Scott HM (1965) The development of an amino acid reference diet for the early growth of chicks. Poult Sci 44:803-808

Dessimoni GVI, Dalólio FS, Moreira J, Teixeira LV, Bertechini AGV (2019) Protease supplementation under amino acid reduction in diets formulated with different nutritional requirements for broilers. Braz $\mathbf{J}$ Poult Sci 21:1-8

Dong X, Yang C, Tang S, Jiang Q, Zou X (2010) Effect and mechanism of glutamine on productive performance and egg quality of laying hens. Asian Australas J Anim Sci 23:1049-1056

Emadi M, Jahanshiri F, Kaveh K, Hair-Bejo K, Ideris A, Alimon AR (2011) Nutrition and immunity: the effects of the combination of arginine and tryptophan on growth performance, serum parameters and immune response in broiler chickens challenged with infectious bursal disease vaccine. Avian Pathol 40:63-72

Erwan E, Tomonaga S, Yoshida J, Nagasawa M, Ogino Y, Denbow DM, Furuse M (2012) Central administration of L- and D-aspartate attenuates stress behaviors by social isolation and CRF in neonatal chicks. Amino Acids 43:1969-1976

Erwan E, Chowdhury VS, Nagasawa M, Goda R, Otsuka T, Yasuo S, Furuse M (2014) Central injection of L- and D-aspartate attenuates isolation induced stress behavior in chicks possibly through different mechanisms. Eur J Pharmacol 736:138-142 
Fang YZ, Yang S, Wu G (2002) Free radicals, antioxidants, and nutrition. Nutrition 18:872-879

Fisher H, Scott HM (1954) The essential amino acid requirements of chicks as related to their proportional occurrence in the fat-free carcass. Arch Biochem Biophys 51:517-519

Flynn NE, Wu G (1996) An important role for endogenous synthesis of arginine in maintaining arginine homeostasis in neonatal pigs. Am J Physiol 271:R1149R1155

Fouad AM, Ei-Senousey HK, Yang XJ, Yao JH (2013) Dietary L-arginine supplementation reduces abdominal fat content by modulating lipid metabolism in broiler chickens. Animal 7:1239-1245

Fu WJ, Haynes TE, Kohli R, Hu J, Shi W, Spencer TE, Carroll RJ, Meininger CJ, Wu G (2005) Dietary $\mathrm{L}$-arginine supplementation reduces fat mass in Zucker diabetic fatty rats. J Nutr 135:714-721

Furukawa K, He WL, Leyva-Jimenez H, Bailey CA, Bazer FW, Toyomizu M, Wu G (2018) Developmental changes in the activities of enzymes for polyamine synthesis in chickens. Poult Sci 97(E-Suppl 1):3-4

Furukawa K, Kikusato M, Wu G, Toyomizu M (2020) Suppressive effects of glutamate and glutamine co-supplementation on muscle proteolysis in heatstressed broiler chickens. Poultry Science Association Annual Meeting

Gholipour V, Chamani M, Shahryar HA, Sadeghi A, Afshar MA (2017) Effects of dietary L-glutamine supplement on performance, egg quality, fertility and some blood biochemical parameters in Guinea fowls (Numida meleagris). Kafkas Univ Vet Fak Derg 23:903-910

Gilbert ER, Li H, Emmerson DA, Webb KE Jr, Wong EA (2010) Dietary protein composition influences abundance of peptide and amino acid transporter messenger ribonucleic acid in the small intestine of 2 lines of broiler chicks. Poult Sci 89:1663-1676

Glista WA, Mitchell HH, Scott HM (1951) The amino acid requirements of the chick. Poult Sci 30:915

Graber G, Baker DH (1973) The essential nature of glycine and proline for growing chickens. Poult Sci 52:892-896

Hamasu K, Haraguchi T, Kabuki Y, Adachi N, Tomonaga S, Sato H, Denbow DM, Furuse M (2009) L-Proline is a sedative regulator of acute stress in the brain of neonatal chicks. Amino Acids 37:377-382

Hamasu K, Shigemi K, Tsuneyoshi Y, Yamane H, Sato H, Denbow DM, Furuse M (2010) Intracerebroventricular injection of 1-proline and d-proline induces sedative and hypnotic effects by different mechanisms under an acute stressful condition in chicks. Amino Acids 38:57-64

Haraguchi T, Tomonaga S, Kurauchi I, Hamasu K, Sato H, Denbow DM, Furuse M (2007) Intracerebroventricular injection of 1-proline modifies food intake in neonatal chicks. J Anim Vet Adv 6:1255-1257

He WL, Wu G (2020) Metabolism of amino acids in the brain and their roles in regulating food intake. Adv Exp Med Biol 1265:167-185
He WL, Furukawa K, Leyva-Jimenez H, Bailey CA, Wu G (2018) Oxidation of energy substrates by enterocytes of 0- to 42-day-old chickens. Poult Sci 97(E-Suppl 1):3

Herring CM, Bazer FW, Wu G (2020) Amino acid nutrition for optimum growth, development, reproduction, and health of zoo animals. Adv Exp Med Biol 1285:233-253

Hou YQ, Wu G (2017) Nutritionally nonessential amino acids: a misnomer in nutritional sciences. Adv Nutr 8:137-139

Hou YQ, Wu G (2018) L-Glutamate nutrition and metabolism in swine. Amino Acids 50:1497-1510

Hou YQ, Wu ZL, Dai ZL, Wang GH, Wu G (2017) Protein hydrolysates in animal nutrition: industrial production, bioactive peptides, and functional significance. J Anim Sci Biotechnol 8:24

Hou YQ, He WL, Hu SD, Wu G (2019) Composition of polyamines and amino acids in plant-source foods for human consumption. Amino Acids 51:1153-1165

Hu H, Bai X, Shah AA, Wen AY, Hua JL, Che CY, He SJ, Jiang JP, Cai ZH, Dai SF (2016a) Dietary supplementation with glutamine and $\gamma$-aminobutyric acid improves growth performance and serum parameters in 22- to 35-day-old broilers exposed to hot environment. J Anim Physiol Anim Nutr 100:361-370

Hu H, Bai X, Wen A, Shah AA, Dai S, Ren Q, Wang S, He S, Wang L (2016b) Assessment of interactions between glutamine and glucose on meat quality, AMPK, and glutamine concentrations in pectoralis major meat of broilers under acute heat stress. J Appl Poult Res 25:370-378

Huston RL, Scott HM (1968) Effect of varying the composition of crystalline amino acid mixture on weight gain and pattern of free amino acids in chick tissue. Fed Proc 27:1204-1209

Izumi T, Kawamura K, Ueda H, Bungo T (2004) Central administration of leucine, but not isoleucine and valine, stimulates feeding behavior in neonatal chicks. Neurosci Lett 354:166-168

Jobgen WJ, Meininger CJ, Jobgen SC, Li P, Lee MJ, Smith SB, Spencer TE, Fried SK, Wu G (2009) Dietary L-arginine supplementation reduces white-fat gain and enhances skeletal muscle and brown fat masses in dietinduced obese rats. J Nutr 139:230-237

Johnson CA, Duong T, Latham RE, Shirley RB, Lee JT (2020) Effects of amino acid and energy density on growth performance and processing yield of mixed-sex Cobb $700 \times$ MV broiler chickens. J Appl Poult Res 29:269-283

Kawakami S-I, Bungo T, Ohgushi A, Ando R, Shimojo M, Masuda Y, Denbow DM, Furuse M (2000) Brainderived mast cells could mediate histamine-induced inhibition of food intake in neonatal chicks. Brain Res 857:313-316

Klain G, Johnson BC (1962) Metabolism of labeled aminoethanol, glycine, and arginine in the chick. J Biol Chem 237:123-126

Klain GJ, Scott HM, Johnson BC (1960) The amino acid requirements of the growing chick fed a crystalline amino acid diet. Poult Sci 39:39-44 
Kluess HA, Stafford J, Evanson KW, Stone AJ, Worley J, Wideman RF (2012) Intrapulmonary arteries respond to serotonin and adenosine triphosphate in broiler chickens susceptible to idiopathic pulmonary arterial hypertension. Poult Sci 91:1432-1440

Lemme A (2009) Amino acid recommendations for laying hens. Lohmann Inf 44:21-32

Leveille GA, Fisher H (1959) Amino acid requirements for maintenance in the adult rooster. II The requirements for glutamic acid, histidine, lysine and arginine. J Nutr 69:289-294

Li P, Wu G (2018) Roles of dietary glycine, proline and hydroxyproline in collagen synthesis and animal growth. Amino Acids 50:29-38

Li P, Wu G (2020) Composition of amino acids and related nitrogenous nutrients in feedstuffs for animal diets. Amino Acids 52:523-542

Li P, Kim SW, Nakagawa K, Zhou HJ, Wu G (2010) Dietary supplementation with L-glutamine and AminoGut ${ }^{\mathrm{TM}}$ enhances protein synthesis in skeletal muscle of growing broiler chickens. FASEB J 24:740.21

Li XL, Rezaei R, Li P, Wu G (2011) Composition of amino acids in feed ingredients for animal diets. Amino Acids 40:1159-1168

Li XL, Zheng SX, Wu G (2020a) Nutrition and metabolism of glutamate and glutamine in fish. Amino Acids 52:671-691

Li WW, Yang JC, LYU QF, Wu GF, Lin SM, Yang QG, Hu JM (2020b) Taurine prevents cardiomyocyte apoptosis by inhibiting the calpain-1/cytochrome c pathway during RVH in broilers. Amino Acids 52:453-463

Liu SY, Selle PH, Raubenheimer D, Cadogan DJ, Simpson SJ, Cowieson AJ (2016) An assessment of the influence of macronutrients on growth performance and nutrient utilisation in broiler chickens by nutritional geometry. Br J Nutr 116:2129-2138

Maruyama K, Sunde ML, Harper AE (1976) Is L-glutamic acid nutritionally a dispensable amino acid for the young chick? Poult Sci 55:45-60

Matthews JC (2000) Amino acid and peptide transport system. In: Farm animal metabolism and nutrition. JPF D'Mello CAPI Publishing, Wallingford, pp 3-23

McNeill SH, Belk KE, Campbell WW, Gifford CL (2017) Coming to terms: meat's role in a healthful diet. Anim Front 7:34-42

Mund MD, Riaz M, Mirza MA, Rahman Z, Mahmood T, Ahmad F, Ammar A (2020) Effect of dietary tryptophan supplementation on growth performance, immune response and antioxidant status of broiler chickens from 7 to 21 days. Vet Med Sci 6:48-53

Nakashima K, Yakabe Y, Ishida A, Yamazaki M, Abe H (2007) Suppression of myofibrillar proteolysis in chick skeletal muscles by a-ketoisocaproate. Amino Acids 33:499-503

Nakashima K, Yakabe Y, Ishida A, Katsumata M (2008) Effects of orally administered glycine on myofibrillar proteolysis and expression of proteolytic-related genes of skeletal muscle in chicks. Amino Acids 35:451-456
NRC (National Research Council) (1994) Nutrient requirements of poultry, 9th edn. National Academy Press, Washington, DC

Osmanyan AK, Ghazi Harsini S, Mahdavi R, Fisinin VI, Arkhipova AL, Glazko TT, Kovalchuk SN, Kosovsky GY (2018) Intestinal amino acid and peptide transporters in broiler are modulated by dietary amino acids and protein. Amino Acids 50:353-357

Oso AO, Williams GA, Oluwatosin OO, Bamgbose AM, Adebayoc AO, Olowofeso O, Pirgozliev V, Adegbenjo AA, Oshoe SO, Alabi JO, Li F, Liu H, Yao K, Xin W (2017) Effect of dietary supplementation with arginine on haematological indices, serum chemistry, carcass yield, gut microflora, and lymphoid organs of growing turkeys. Livest Sci 198:58-64

Ospina-Rojas IC, Murakami AE, Oliveira CAL, Guerra AFQG (2013) Supplemental glycine and threonine effects on performance, intestinal mucosa development, and nutrient utilization of growing broiler chickens. Poult Sci 92:2724-2731

Pirsaraei ZA, Rahimi A, Deldar H, Sayyadi AJ, Ebrahimi M, Shahneh AZ, Shivazad M, Tebianian M (2017) Effect of feeding arginine on the growth performance, carcass traits, relative expression of lipogenic genes, and blood parameters of Arian broilers. Braz J Poult Sci 20:363-370

Porteous JW (1980) Glutamate, glutamine, aspartate, asparagine, glucose and ketone-body metabolism in chick intestinal brush-border cells. Biochem J 188:619-632

Price WA Jr, Taylor MW, Russell WC (1953) The retention of essential amino acids by the growing chick. J Nutr 51:413-422

Reeds PJ, Burrin DG, Stoll B, Jahoor F (2000) Intestinal glutamate metabolism. J Nutr 130:978S-982S

Refaie AM, Abdallah AG, Khosht AR, Magied HAA, Habib HH, Waly AH, Shaban SAM (2017) Response of broiler chicks to low-protein-L-valine supplemented diets formulated based on digestible amino acids. J Anim Poult Prod 8:13-19

Réhault-Godbert S, Guyot N, Nys Y (2019) The Golden egg: nutritional value, bioactivities, and emerging benefits for human health. Nutrients 11:684

Robel E, Menge H (1973) Performance of chicks fed an amino acid profile diet based on carcass composition. Poult Sci 52:1219-1221

Sasse CE, Baker DH (1973) Modification of the Illinois reference standard amino acid mixture. Poult Sci 52:1970-1972

Sestili P, Martinelli C, Colombo E, Barbieri E, Potenza L, Sartini S, Fimognari C (2011) Creatine as an antioxidant. Amino Acids 40:1385-1396

Smith DD, Campbell JW (1983) Subcellular location of chicken brain glutamine synthetase and comparison with chicken liver mitochondrial glutamine synthetase. J Biol Chem 258:12265-12268

Tan BE, Yin YL, Liu ZQ, Li XG, Xu HJ, Kong XF, Huang RL, Tang WJ, Shinzato I, Smith SB, Wu G (2009) Dietary L-arginine supplementation increases muscle gain and reduces body fat mass in growing-finishing pigs. Amino Acids 37:169-175 
Tan JZ, Guo YM, Applegate TJ, Du EC, Zhao X (2014) Dietary L-arginine modulates immunosuppression in broilers inoculated with an intermediate strain of infectious bursa disease virus. J Sci Food Agric 95:126-135

Tinker DA, Brosnan JT, Herzberg GR (1986) Interorgan metabolism of amino acids, glucose, lactate, glycerol and uric acid in the domestic fowl (Gallus domesticus). Biochem J 240:829-836

Tomonaga S, Tachibana T, Takagi T, Saito E-S, Zhang R, Denbow DM, Furuse M (2004) Effect of central administration of carnosine and its constituents on behaviors in chicks. Brain Res Bull 63:75-82

Tomonaga S, Kaji Y, Tachibana T, Denbow DM, Furuse M (2005) Oral administration of b-alanine modifies carnosine concentrations in the muscles and brains of chickens. Anim Sci J 76:249-254

Tran PV, Chowdhury VS, Do PH, Bahry MA, Yang H, Furuse M (2016) L-Ornithine is a potential acute satiety signal in the brain of neonatal chicks. Physiol Behav 155:141-148

Tran PV, Chowdhury VS, Furuse M (2019) Central regulation of feeding behavior through neuropeptides and amino acids in neonatal chicks. Amino Acids 51:1129-1152

Wang WW, Wu ZL, Dai ZL, Yang Y, Wang JJ, Wu G (2013) Glycine metabolism in animals and humans: implications for nutrition and health. Amino Acids 45:463-477

Wang WW, Dai ZL, Wu ZL, Lin G, Jia SC, Hu SD, Dahanayaka S, Wu G (2014) Glycine is a nutritionally essential amino acid for maximal growth of milk-fed young pigs. Amino Acids 46:2037-2045

Watford M, Wu G (2005) Glutamine metabolism in uricotelic species: variation in skeletal muscle glutamine synthetase, glutaminase, glutamine levels and rates of protein synthesis. Comp Biochem Physiol B Biochem Mol Biol 140:607-614

Watford M, Hod Y, Chiao YB, Utter MF, Hanson RW (1981) The unique role of the kidney in gluconeogenesis in the chicken. The significance of a cytosolic form of phosphoenolpyruvate carboxykinase. J Biol Chem 256:10023-10027

Wen C, Wu P, Chen YP, Wang T, Zhou YM (2014) Methionine improves the performance and breast muscle growth of broilers with lower hatching weight by altering the expression of genes associated with the insulin-like growth factor-I signaling pathway. $\mathrm{Br} \mathrm{J}$ Nutr 111:201-206

Winiarska-Mieczan A, Kwiecień M, Kwiatkowska K, Baranowska-Wójcik E, Szwajgier D, Zaricka E (2020) Fatty acid profile, antioxidative status and dietary value of the breast muscle of broiler chickens receiving glycine- $\mathrm{Zn}$ chelates. Anim Prod Sci 60:1095-1102

Wu G (2009) Amino acids: metabolism, functions, and nutrition. Amino Acids 37:1-17

Wu G (2010) Functional amino acids in growth, reproduction and health. Adv Nutr 1:31-37

Wu G (2013) Amino acids: biochemistry and nutrition. CRC Press, Boca Raton
Wu G (2014) Dietary requirements of synthesizable amino acids by animals: a paradigm shift in protein nutrition. J Anim Sci Biotechnol 5:34

Wu G (2018a) Principles of animal nutrition. CRC Press, Boca Raton

Wu G (2018b) Functional amino acids in poultry nutrition: recent developments and practical applications. Annual Meeting of Poultry Science Association, San Antonio. July 23-26, 2018

Wu G (2020a) Management of metabolic disorders (including metabolic diseases) in ruminant and nonruminant animals. In: Bazer FW, Lamb GC, Wu G (eds) Animal agriculture: challenges, innovations, and sustainability. Elsevier, New York, pp 471-492

Wu G (2020b) Important roles of dietary taurine, creatine, carnosine, anserine and hydroxyproline in human nutrition and health. Amino Acids 52:329-360

Wu G, Thompson JR (1987) Ketone bodies inhibit leucine degradation in chick skeletal muscle. Int J Biochem 19:937-943

Wu G, Thompson JR (1990) The effect of glutamine on protein turnover in chick skeletal muscle in vitro. Biochem J 265:593-598

Wu G, Thompson JR, Sedgwick G, Drury M (1989) Formation of alanine and glutamine in chick (Gallus domesticus) skeletal muscle. Comp Biochem Physiol 93B:609-613

Wu G, Thompson JR, Baracos VE (1991) Glutamine metabolism in skeletal muscle from the broiler chick (Gallus domesticus) and the laboratory rat (Rattus norvegicus). Biochem J 274:769-774

Wu G, Borbolla AG, Knabe DA (1994) The uptake of glutamine and release of arginine, citrulline and proline by the small intestine of developing pigs. J Nutr 124:2437-2444

Wu G, Flynn NE, Yan W, Barstow DG (1995) Glutamine metabolism in chick enterocytes: absence of pyrroline5-carboxylate synthase and citrulline synthesis. Biochem J 306:717-721

Wu G, Chung-Bok M, Vincent N, Kowalski TJ, Choi YH, Watford M (1998) Distribution of phosphate-activated glutaminase isozymes in the chicken: absence from liver but presence of high activity in pectoralis muscle. Comp Biochem Physiol B 120:285-290

Wu G, Bazer FW, Burghardt RC, Johnson GA, Kim SW, Knabe DA, Li P, Li XL, McKnight JR, Satterfield MC, Spencer TE (2011a) Proline and hydroxyproline metabolism: implications for animal and human nutrition. Amino Acids 40:1053-1063

Wu G, Bazer FW, Johnson GA, Knabe DA, Burghardt RC, Spencer TE, Li XL, Wang JJ (2011b) Important roles for L-glutamine in swine nutrition and production. $\mathbf{J}$ Anim Sci 89:2017-2030

Wu ZL, Hou YQ, Dai ZL, Hu CA, Wu G (2019) Metabolism, nutrition and redox signaling of hydroxyproline. Antioxid Redox Signal 30:674-682

Wu G, Bazer FW, Lamb GC (2020) Significance, challenges and strategies of animal production. In: Bazer FW, Lamb GC, Wu G (eds) Animal agriculture: challenges, innovations, and sustainability. Elsevier, New York, pp 1-20 
Xiao M, Mi YL, Liu LJ, Lv CF, Zeng WD, Zhang CQ, Li J (2018) Taurine regulates mucosal barrier function to alleviate lipopolysaccharide-induced duodenal inflammation in chicken. Amino Acids 50:1637-1646

Yamane H, Tsuneyoshi Y, Denbow DM, Furuse M (2009a) N-methyl-D-aspartate and a-amino-3hydroxy-5-methyl-4isoxazolepropionate receptors involved in the induction of sedative effects under an acute stress in neonatal chicks. Amino Acids 37:733-739

Yamane H, Asechi M, Tsuneyoshi Y, Kurauchi I, Denbow DM, Furuse M (2009b) Intracerebroventricular injection of L-aspartic acid and L-asparagine induces sedative effects under an acute stressful condition in neonatal chicks. Anim Sci J 80:286-290

Yasugi S, Mizuno T (1981) Developmental changes in acid proteases of the avian proventriculus. J Exp Zool A 216:331-335

Yazdanabadi FI, Moghaddama GH, Nematollahib A, Daghighkiaa H, Sarirc H (2020) Effect of arginine supplementation on growth performance, lipid profile, and inflammatory responses of broiler chicks challenged with coccidiosis. Prev Vet Med 180:105031
Yoshida J, Tomonaga S, Ogino Y, Nagasawa M, Kurata K, Furuse M (2012) Intracerebroventricular injection of kynurenic acid attenuates corticotrophinreleasing hormone-augmented stress responses in neonatal chicks. Neuroscience 220:142-148

Zarghi H, Golian A, Nikbakhtzade M (2020) Effect of dietary digestible lysine level on growth performance, blood metabolites and meat quality of broilers 23-38 days of age. J Anim Physiol Anim Nutr 104:156-165

Zhai W, Peebles ED, Wang X, Gerard PD, Olanrewaju HA, Mercier Y (2016) Effects of dietary lysine and methionine supplementation on Ross 708 male broilers from 21 to $42 \mathrm{~d}$ of age (III): serum metabolites, hormones, and their relationship with growth performance. J Appl Poult Res 25:223-231

Zhang S, Saremi B, Gilbert ER, Wong EA (2017a) Physiological and biochemical aspects of methionine isomers and a methionine analogue in broilers. Poult Sci 96:425-439

Zhang Y, Zhao L, Zhou Y, Diao C, Han L, Yinjie N, Liu S, Chen H (2017b) Glutamine ameliorates mucosal damage caused by immune responses to duck plague virus. Dose-Response. https://doi.org/10.1177/15593258177 08674

Open Access This chapter is licensed under the terms of the Creative Commons Attribution 4.0 International License (http://creativecommons.org/licenses/by/4.0/), which permits use, sharing, adaptation, distribution and reproduction in any medium or format, as long as you give appropriate credit to the original author(s) and the source, provide a link to the Creative Commons licence and indicate if changes were made.

The images or other third party material in this chapter are included in the chapter's Creative Commons licence, unless indicated otherwise in a credit line to the material. If material is not included in the chapter's Creative Commons licence and your intended use is not permitted by statutory regulation or exceeds the permitted use, you will need to obtain permission directly from the copyright holder.

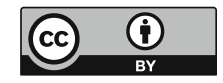

